\title{
THE COURTS, CONGRESS, AND EXECUTIVE POLICY-MAKING: NOTES ON THREE DOCTRINES
}

\author{
Paul Gewirtz*
}

\section{INTRODUCTION}

My starting point is an increasingly common description of reality: that there has been a continuing flow of policy-making power from Congress to the executive; that as a result the executive makes major policy which has not been affirmatively endorsed by Congress; and that this is a significant problem in our constitutional system. Against the background of frequent arguments that Congress' role in policy-making should be strengthened and protected to assure an appropriate allocation of power in our system, I consider here whether the courts should play some role in furthering that objective.

The question is an extremely complex one. A persuasive answer would require a full analysis of various legal doctrines; questions of political and constitutional theory; the actual behavior of political and administrative bodies in making policy; the practicality of greater congressional policy-making in various areas; and all of the alternative means of controlling executive policy-making. This conference paper, prepared over a few weeks by a practicing attorney relatively new to the specific subject at hand, is obviously not such an effort. My purpose at this point is simply to be suggestive about several legal doctrines- to set forth a position which, I believe, at least deserves further consideration, even though I recognize that ultimately it may not prove fruitful.

In only a very preliminary and tentative way, then, I argue that the courts can and should play some role in stemming the flow of policy-making power away from Congress. The judicial weapons are limited, however, and the appropriate judicial role at most a modest one; and the effort is useless unless Congress is willing and able, with a little encouragement, to reclaim a more decisive policy-making role. I discuss three methods that the courts have used or might use to curb executive policy-making and recall Congress to a greater policy-making role: applying the delegation doctrine narrowly construing statutes which do not clearly and explicitly authorize executive policy-making and construing statutes so as to preempt any inherent presidential power to make policy. ${ }^{1}$ In a brief final section, I add some more general observations on the

\footnotetext{
* Attorney, Center for Law and Social Policy, Washington, D.C.

1. There are numerous other things that the courts could do to protect Congress policymaking role against the executive: For example, the courts could directly limit the President claims to inherent policy-making powers, Youngstown Sheet \& Tube Co. v. Sawyer, 343 U.S. 579
} 
subject. Although the focus of this symposium is the executive branch, my thoughts are at least as applicable to policy-making by the independent agencies, and therefore I refer to them as well in my discussion.

\section{I}

\section{Who Should Make Policy?}

My main premise throughout this paper is itself the subject of considerable debate, but cannot be explored in any adequate way here. It is, essentially, that under our Constitution Congress is the favored institution in our national government for major policy-making-that is, making those basic value choices which have large impact and usually govern other decisions. To be sure, the other institutions all have legitimate policy-making functions. The executive has constitutional powers and duties that involve important policymaking, particularly in foreign affairs, and it influences policy through initiating and vetoing legislation; both the executive and the independent agencies inevitably must make some policy in the course of administering the law; the judiciary also inevitably makes policy in applying statutes, tending the federal common law and interpreting the Constitution. These intermeshing policymaking functions are some of the clearest examples of interdependence among the several "separate" branches of our political system.

But while policy-making is shared, and the constitutional phrases "legislative powers" and "executive power" may have somewhat overlapping connotations, the framers of the Constitution seem clearly to have intended Congress, through exercise of article I's enumerated and incidental "legislative powers," to be the main policy-maker. This constitutional preference for congressional policy-making rests upon at least two factors other than the constitutional text.

First, in a democracy legislatures are usually thought to be more purely representative in composition and process. Compared with the "winner take all" presidency and the unelected agencies, Congress and its committees contain within them a diversity of elected voices that mirrors the country's variety; shifting moods in the country and different perspectives will always find a way to be presented. Consultation and collaboration are a central aspect of the legislative process; isolated decisions, a demonstrated danger of the "imperial presidency," are impossible. ${ }^{2}$

(1952) (opinion of Black, J.): enforce congressional subpoenas for documents and other materials within the executive branch necessary for congressional policy-making, but see Senate Select Comm. v. Nixon, 498 F.2d 725 (D.C. Cir. 1974); and restrict the President's use of the pocket veto, Kennedy v. Sampson, 511 F.2d 430 (D.C. Cir. 1974).

2. Moreover, the President and Vice President are the only elected figures in the executive branch, and therefore most executive branch decisions are made by unelected officials; in their second terms, the President and Vice President are themselves unaccountable lame ducks. By contrast, there are 535 elected Congresspersons, a large number of whom decide to run for 
Second, our system of constitutional checks and balances depends upon Congress' role as policy-maker. The congressional power to make policy, along with the power to appropriate funds, makes the executive and agencies dependent upon Congress, and is therefore the source of Congress' ability to check and balance these other institutions. If the executive exercises comprehensive policy-making power, Congress' checking function is thereby weakened. The fear, at bottom, is that executive lawmaking, once legitimated, cannot be bounded, and that tyranny is possible.

To say this simplifies an enormously complex legal subject, as well as an enormously complex real world. Most people would agree, I suspect, that in theory independent agencies should generally not be making basic value choices for the society. But the status of the executive branch, headed by an elected president, is more problematic. In important senses the President is a representative of the people and, most of the time, of a national majority. In many ways Congress and its committees are undemocratic, uninformed and oriented towards local constituencies. For these reasons and others (to which I will return), the executive properly plays a significant role in the policymaking process. The Constitution gives the President the explicit authority to veto legislation if his views are not adequately reflected. ${ }^{3}$ The Constitution also authorizes the President to "recommend" legislation that "he shall judge necessary and expedient." 4 The enormous persuasive powers of the modern presidency, as well as its still unequaled capacity to prepare a national budget, assure that the President's proposals will greatly influence, if not dominate, the legislative process. Nevertheless, it remains the constitutional scheme that major presidential initiatives properly do not become law until Congress as a body reviews them and affirmatively approves and accepts responsibility for them. Congress is at least a necessary partner in major policy-making decisions.

The real world, of course, may intrude to demonstrate the impracticality or foolishness of any theoretical preferences and to temper constitutionalism. It may be, as many have argued, that modern conditions require vast executive and agency policy-making, hedged in at most by limited juclicial review, sporadic and after-the-fact congressional oversight, infrequent national elections, and norms of executive self-control. As I elaborate below, however, I have not yet been persuaded that it is unrealistic and wrongheaded to insist that Congress assume direct responsibility for the major policies to guide the country. ${ }^{5}$ History does demonstrate the weaknesses of all the branches, but

reelection every few years; and in many wavs they are closer 10 , more responsive 10 , and more directly accountable to the people than the President.

3. U.S. Const. art I, $\S 7$.

4. U.S. Const. art. 1I. \$3.

5. See notes 46-59 infra and accompanying text. Obstacles to a strengthened congressional role are also discussed at notes $142-44$ infra and accompanying text. 
recent history makes particularly clear that the executive and agencies are not inherently wise, or even decisive. We have had enough experience to know that the so-called expertise of the executive branch and independent agencies is to a considerable extent a myth; in any event, issues of policy involve questions of value, which are usually thought to be matters for broadly democratic, not expert, decision. We also know that, left on his own, the President can do dangerous things.

The question of who should make policy is at the heart of most discussion of the contemporary problem of executive power. For me, the making of major policy by the executive and agencies is a challenge to basic constitutional principle. It therefore becomes worth while to think about doctrines that the courts might use to deal with the challenge.

\section{Should the Delegation Doctrine Be Revived?}

Congress' delegation of power to the executive and agencies accounts for much of the growth in executive and agency power. ${ }^{6}$ From the beginning, it was understood that delegation of Congress' article I powers in our system of separation of powers poses at least a potential constitutional problem appropriate for judicial resolution. In addition to a general concern for our system of checks and balances, the objection to delegated congressional power reflects, as Professor Jaffe and others have noted, "a fundamental democratic concern," a "concern that large decisions of policy should be grounded in consent" arrived at through representation in the legislature." Although the courts occasionally formulated extreme and simplistic statements that "the legislative power of Congress cannot be delegated," ${ }^{8}$ it was established very

6. See. e.g.. A. Schlesinger Jr., The Imperial Presidency (1973); T. Sorenson. Watchmen in the Night 85 (1975); Baker, What Presidential Pouters Should Be Cut? in Has the President Too Much Power? 42 (C. Roberts ed. 1973); Freedman, Crisis and Legitimacy in the Admimistrative Process, 27 Stan. L. Rev. 1041 (1975); California Bankers Assn. v. Schultz, 416 U.S. 21, 90-91 (1974) (Douglas, J.. dissenting).

7. Jaffe, An Essay on Delegation of Legislative Power: I, 47 Colum. L. Rev. 359, 359-60 (1947). See also A. Bickel, The Least Dangerous Branch 160 (1962); compare H. Friendly, The Federal Administrative Agencies 21-22 (1962); E. Freund, Administrative Powers Over Persons and Property 218-21, $582-83$ (1928); L. Jaffe. Judicial Control of Administrative ACTION 85 (1965); Stewart. The Reformation of American Administratize Law, 88 HaRv. L. REv. 1667 , 1672-73. 1694 (1975); Wright, Book Review, Beyond Discretionary Justice, 81 Yale L.J. 575, 580, $582-87$ (1972); United States v. Robel, 389 U.S. 258, 276 (1967) (Brennan, J., concurring in the result); Zemel v. Rusk, 381 U.S. 1, 20 (1965) (Black, J., dissenting); Arizona v. California. 373 U.S. 546, 626 (1963) (Harlan, J., dissenting). Where individual liberties are involved, the objection to delegated power may also reflect "due process" notions. See, e.g., Cushman, The Constitutional Status of the Independent Regulator Commissions, 24 CoRnell L.Q. 13. 32-33 (1938); note 35 infra. For a discussion of other historic bases for the delegation doctrine, see, e.g., Duff and Whiteside, Delegata Potestas Non Potest Delegari: A Maxim of American Constitutional Law, 14 Cornell L.Q. 168,195 (1929).

8. United States v. Shreveport Grain \& Elevator Co., 287 U.S. 77, 85 (1932). 
early that Congress' power could be delegated provided that Congress had made the basic policy choices and therefore given sufficient guidance concerning how it wished the delegated power to be exercised. Delegation of some power, it was understood, was often a practical necessity given the things that modern government did. Delegations were permissible, the courts said, provided that the delegated legislative power was accompanied by "declared policies"9 or prescribed "standards"1" or "intelligible principles"11 to which the delegate must conform. Congress had to decide the "important" questions; the delegate could "fill up the details." 12 These formulations, whatever their differences, are all directly responsive to the "fundamental democratic concern" and the concern for checks and balances, for they indicate that basic policy-making must be made in Congress. ${ }^{13}$ Only relatively minor and interstitial policy-making that was a necessary part of the application and administration of congressional policies could be delegated.

While the rhetoric of the delegation doctrine points to an accommodation between Congress' law-making duties under article I and the needs of a working government, the courts have generally not applied their own rhetoric. The most famous exceptions were A.L.A. Schechter Poultry Corporation v. United States ${ }^{14}$ and Panama Refining Co. $\%$. Ryan,${ }^{15}$ striking down portions of the National Industrial Recovery Act as unlawful delegations to the President. But since then, the federal courts have been perfectly prepared to uphold essentially standardless statutes that left the most basic policy-making to others. ${ }^{16}$ In general, the courts have asserted that the statutes in question provided

9. E.g., Panama Refining Co. v. Ryan, 293 U.S. 388, 415, 421, 430 (1935) ("[W]e look to the statute to see whether the Congress has declared a policy with respect to that subject . . .."); see United States v. Robel, 389 U.S. 258, 275-77 (1967) (Brennan, J., concurring in the result).

10. E.g., United States v. Chicago, Milwaukee, St. Paul \& Pacific R.R., 282 U.S. 311,324 (1931) (Congress cannot delegate any part of its legislative power except under the limitation of a prescribed standard . ..."); Yakus v. United States, 321 U.S. 414, 426 (1944) (there is unlawful delegation only where "there is an absence of standards for the guidance of the Administrator's action, so that it would be impossible in a proper proceeding to ascertain whether the will of Congress has been obeyed ....").

11. E.g., J.W. Hampton, Jr. \& Co. v. United States, 276 U.S. 394, 409 (1928) ("If Congress shall lay down by legislative act an intelligible principle to which the person or body authorized to [act] is directed to conform, such legislative action is not a forbidden delegation of legislative power.").

12. Wayman v. Southard, 23 U.S. (10 Wheat) 1.43 (1825).

13. There are, of course, a number of different ways that Congress can express a policy choice-_e.g., as a rule, as guiding principles, as a series of weighted factors. However, these differences do not, I believe, effect the basis thrust of this paper and are not developed here.

14. 295 U.S. 495 (1935).

15. 293 U.S. 388 (1935). In Carter v. Carter Coal Co., 298 U.S. 238 (1936), the Supreme Court struck down the Bituminous Coal Conservation Act, in part because it delegated significant powers to prizate persons.

16. Some state courts have continued to apply the doctrine. See K. Davis, Administrative LAw Treatise \$ 2.07-.15 (1958); Jaffe, An Essay on Delegation of Legislative Power: 11, 47 Colum. L. Rev. 561, 581 (1947); Wright, supra note 7, at 583 n.25; Recent Developments, State Statutes Delegating Legislative Power Need Not Prescribe Standards, 14 Stan. L. Rev. 372 (1962). 
adequate guidance, when in fact Congress provided no guidance on basic policy issues at all. The failure of courts to apply the delegation doctrine in a meaningful way has removed a potentially important incentive for Congress to write more specific statutes, and has contributed to the growth of executive and agency power.

Examples are numerous. ${ }^{17}$ Three will suffice here. The Supreme Court has upheld a statute authorizing the Federal Communications Commission to license radio and television stations as the "public convenience, interest, or necessity" warrant. ${ }^{18}$ Lichter $\%$. United States ${ }^{19}$ upheld a statute authorizing the War Department to recover "excessive profits" under war contracts. More recently, in Amalgamated Meat Cutters \%. Connally, a three-judge district court upheld the Economic Stabilization Act of 1970, which authorized the President, if he chose to do so, "to issue such orders and regulations as he may deem appropriate to stabilize prices, rents, wages, and salaries at levels not less than those prevailing on May 25, 1970."20 These and numerous other statutes, tested and untested, grant power without clear policy. The hard but basic value choices are left to others, often masked behind mandates to act fairly, appropriately, or in the public interest. Some statutes list factors to be considered, but often the factors conflict with each other and no guidance is given on how the conflicting policy goals are to be weighted and resolved. ${ }^{21}$

A large price appears to be paid when congressional power is delegated without standards, guiding principles, or clear policy objectives, whatever the subject matter area. ${ }^{22}$ First, as already suggested, Congress is weakened and the constitutional legitimacy of governmental action may be called into question when major value questions are resolved by the executive or by independent "experts," rather than by Congress. Second, major policy decisions do not benefit from the collaborative wisdom of both the executive and legislative

17. Many are listed and discussed in Jaffe, An Essay on Delegation of Legislative Power: $I$ and II, supra note $7 \& 16$; DAvis, supra note 16, $\$ 2.01-.05$ (1958 ed. and 1970 Supp.); Fisher, Delegating Power to the President, 19 J. PuB. L. 251 (1970).

18. F.C.C. v. Pottsville Broadcasting Co., 309 U.S. 134, 137-38 (1940). See also National Broadcasting Co. v. United States, 319 U.S. 190 (1943); Federal Radio Comm. v. Nelson Bros. Bond \& Mortgage Co., 289 U.S. 266 (1933).

19. 334 U.S. $742(1948)$.

20. 337 F. Supp. 737,764 (D.D.C. 1971 ).

21. See Cutler \& Johnson, Regulation and the Political Process, 84 Yale L.J. 1395, 1407-08 (1975); Leventhal, Principled Fairness and Regulaton Urgency, 25 CASE W. Res. L. Rev. 66, 68-69 (1974). A very simple example of this is legislation which authorizes the executive to develop regulatory standards that take account of both safety/environmental and cost factors, but which gives no guidance concerning when the safety/environmental objective should be deemed too expensive. E.g., \& 102(e), Ports and Waterways Safety Act of 1972, 33 U.S.C. \$ 1222(e) (Supp. IV 1974); $\S 6(b)(5)$, Occupational Safety and Health Act of 1970, 29 U.S.C. $\S 655(b)(5)(1970)$.

22. See generally K. Davis, Discretionary Justice (1969); L. JafFe, Judicial Control, supra note 7, at 49; Freedman, supra note 6; T. Lowi, THE End of LiBeralism (1969); Friendly, supra note 7; Merrill, Standards-A Safeguard for the Exercise of Delegated Power, 47 NEb. L. REv. 469 (1968). 
branches. Third, the lack of clear congressional policy choices sets the administrator adrift with unchannelled discretion which makes evenhanded and fair implementation less likely. Fourth, without the clear guidance that standards provide, administrators may be less efficient. Fifth, by delegating major value choices, Congress thrusts enormous political forces and pressures on the executive and independent agencies which can easily deflect them from their more appropriate managerial and "expert" functions. ${ }^{23}$ Sixth, the absence of guiding congressional policy choices means that reviewing courts do not have a substantive standard by which to measure the administrator's action, and therefore their potential usefulness in overseeing and restraining agency action is limited. ${ }^{24}$ Seventh, the lack of guiding principles makes it hard for the public, Congress, and administrative officials to evaluate whether the objectives of the statute are being effectuated. Eighth, the absence of standards makes it difficult for private parties to conform their conduct to law.

Some of these problems could be mitigated by administratively-developed standards and procedural safeguards. Professor Kenneth Davis and others have been masterful advocates for this approach and apparently believe that it is appropriate for courts to require the development of administrative standards. ${ }^{25}$ In his opinion upholding the Economic Stabilization Act of 1970 against a "difficult" delegation challenge, Judge Leventhal noted, as one factor among several that blunted the delegation argument, that the Act (as interpreted) required the President to develop his own "standards" and "intelligible administrative policy." The "contemporary [judicial] approach," Judge Leventhal subsequently wrote, "is one not of invalidating even the broadest statutory delegations of power, but of assuring that they are accompanied by adequate controls on subsequent administrative behavior." 26 There is little doubt that the usual judicial review of administrative action, supplemented by a requirement of administratively-developed standards in the case of broad delegations, can provide significant control over executive action, ${ }^{27}$ particu-

23. H. Friendly, supra note 7. at 22; J. Landis, The Administrative Process 75 (1938); Freedman, supra note 6, at 1060: Gellhorn \& Robinson. Perspectives on Administrative Law. 75 Colum. L. Rev. 771,778 (1975).

24. A similar point is made by Justice Harlan in Arizona $\%$. California, 373 U.S. at 626. Cf. Blumenthal v. Board of Medical Examiners, 57 C.2d 228, 236. 18 Cal. Rptr. 501, 505, 368 P.2d 101, 105 (1962) (Traynor, J.); Joseph Burstyn, Inc. v. Wilson. 343 U.S. 495, 532 (1952) (Frankfurter, J., concurring).

25. K. Davis, supra note 22 , at 57-59; K. Davis, supra note $16 \$ 6.13$, at 278 (Supp. 1970); Wright, supra note 7, at 588-93; Leventhal, supra note 21, at 70; L. Jaffe, Judicial Control. supra note 7, at 71; but see Stewart, supra note 7, at 1699-1702. For cases in which courts have required the executive and administrative agencies to use rulemaking or develop standards, see Davis, Admimistrative Law in the Ruiz Case, 75 Colum. L. Rev. 823, 827-28, n.27 (1975); but see NLRB v. Bell Aerospace Co., 416 U.S. 267 (1974); NLRB v. Wyman-Gordon Co., 394 U.S. 759 (1969)

26. Leventhal, supra note 21 , at 70 .

27. For some interesting observations on whether potential safeguarding mechanisms actually did control the executive's discretion under the Economic Stabilization Act, see J. MAshaw \& R. 
larly since the Administrative Procedure Act has been deemed to reach the President and certainly reaches his subdelegates. ${ }^{28}$

But this judicial/administrative control mechanism does not address the basic problem that policies are being made by the executive and agencies, not by Congress. The Davis approach ignores allocation of powers questions. Davis promises consistency and predictability, but not representative decisionmaking, checks and balances, and constitutional legitimacy. ${ }^{29}$ Nor does his approach permit the courts to play their full role in checking administrative abuses. A basic function of judicial review of administrative action is "to ascertain whether the will of Congress has been obeyed"; 30 if Congress wills no determinate policy-beyond the abdication of its policy-making responsibility-the courts have no independent substantive standard against which to measure what the executive or agency does. Finally, the Davis approach does not seem noticeably easier for courts to apply than the delegation doctrine. As discussed more fully below, one of the major problems with application of the delegation doctrine is that it is difficult for courts to decide whether and to what extent legislative standards should be required in a particular area. The same problem arises when the subject is administrative standards, and the judicial task is not easier. Most courts, of course, have simply abandoned the original delegation doctrine without adopting in its place the Davis approach of requiring administrative standards.

A strengthened judicial application of the original delegation doctrine would be directly responsive to the goals of curbing executive policy-making and encouraging a greater congressional role, and could have a significant effect. Because of the doctrine's present low repute, it is somewhat awkward to discuss the doctrine seriously, much less to suggest its revival. ${ }^{31}$ Nevertheless, the doctrine does at least have an underground life, and surfaces with some vigor from time to time. In a little noticed opinion in 1974, National Cable Television Assn. 2 . United States, the Supreme Court construed the Independent Officers Appropriations Act very narrowly, in a fashion contrary to its apparent scope, in order "to avoid constitutional problems" and "hurdles" posed by standardless delegations under Schechter Poultry and an earlier dele-

Merrill, lNtroduction to the American Public Law System: Cases and Materials $207-12$ (1975).

28. Amalgamated Meat Cutters. 337 F. Supp. at 761 , and authorities cited therein.

29. This is not to deny that the executive and agencies could somewhat strengthen their legitimacy as policy-makers by replicating (or even, it could be said, improving upon) some aspects of the legislative process by assuring that all relevant interests and all points of view are heard and considered before policies are chosen. In fact, administrative law seens to be moving in this direction. See generally Stewart, supra note 7; $f$. Gellhorn \& Robinson, supra note 23.

30. Yakus v. United States, 32! U.S. at 426.

31. See, e.g., Wright, supra note 7 , at 582 (urges doctrine's revival "at the risk of seeming antiquarian"); Gellhorn \& Robinson, supra note 23, at 774-75 (although doctrine is of great interest, it is not "taken seriously by the 'practical' lawyer"). 
gation doctrine case. ${ }^{32}$ The doctrine was squarely relied upon by Justice Harlan (joined by Justices Douglas and Stewart) in his dissent in Arizona \%. California, where he contended that the majority's construction of the Boulder Canyon Project Act permitted delegation of "unrestrained authority to an executive official" (the Secretary of the Interior), and therefore raised, "to say the least, the gravest constitutional doubts [citing, inter alia, Schechter Poultr' and Panama Refining]." ${ }^{33}$ Justice Black wrote a short but stirring dissent endorsing the doc-

32. 415 U.S. 336 (1974). The Court held here and in a companion case, Federal Pouler Commission v. New England Power Co., 415 U.S. 345 (1974), that the Act should be construed as permitting agencies to collect only "fees" measured by the "value to the recipient" of an agency's services. Any other interpretation, the Court said, would effectively give the agencies broad "taxing power" permitting flexible adjustment of the assessment in light of the agency's view of the "public policy or interest served." $I d$. at 336. The two Justices concurring and dissenting stated that the delegation doctrine "is surely as moribund as the substantive due process approach of the same era. ..." [sic], id. at 353, but would also have limited the statute's reach. The majority opinions seem to reflect the Court's particular sensitivity to delegations of the taxing power.

The Supreme Court's recent opinion in Federal Energy Administration \%. Algonquin SNG, Inc., 96 S. Ct. 2295 (1976), handed down after this paper was delivered (and noted more fully at note 93 infra and accompanying text), returns to the more deferential approach. Reversing the court of appeals, the Supreme Court upheld the President's authority to impose multi-billion dollar oil import license fees-the centerpiece of the energy program instituted by Presidents Nixon and Ford after the Arab oil embargo of 1973-under a statute which authorizes the President to "take such action, and for such time, as he deems necessary to adjust the imports of [an] article and its derivatives so that . . . imports [of such article] will not threaten to impair the national security." Inter alia, the Court refused to read the statute narrowly "to avoid 'a serious question of unconstitutional delegation of legislative power" ", since it saw "no looming. problem of improper delegation ...." The Court invoked the traditional requirements that Congress provide "standards" and "intelligible principles" to guide the President's action, but held that these requirements were met here because the statute authorizes the President to act only where he believes that the imports "threaten to impair the national security" and because the statute also sets forth a number of "factors" for the President to consider in exercising his authority. Id. at 2302. (The "factors" mentioned in the statute are extremely broad, however-they include "the economic welfare of the Nation"-and do not seem to limit the President's discretion significantly.) The Court distinguished the delegation here from that in National Cable Television Assn., Inc. 1\%. United States, 415 U.S. 336 (1974), because of what it characterized as the "open-ended nature" of the delegation and the lack of standards in the statute involved in the earlier case. $96 \mathrm{~S}$. Ct. at 2302 n. 10. See note 93 infra and accompanying text.

33. 373 U.S. 546, 626 (1963) (holding that the Secretary of the Interior has authority to allocate water throughout entire southwest region according to his own formula). Justice Harlan added:

The principle that authority granted by the legislature must be limited by adequate standards serves two primary functions vital to preserving the separation of powers required by the Constitution. First, it insures that the fundamental policy decisions in our society will be made not by an appointed official but by the body immediately responsible to the people. Second, it prevents judicial review from becoming merely an exercise at large by providing the courts with some measure against which to judge the official action that has been challenged.

The absence of standards under the Court's construction is an instructive illustration of these points. The unrestrained power to determine the burden of shortages is the power to make a political decision of the highest order. . .

These substantial constitutional doubts do not, of course, lead to the conclusion that the Project Act must be held invalid. Rather, they buttress the conviction, already firmly grounded in the Act and its history, that no such authority was vested in the Secretary by Congress.

Id. at $626-27$. 
trine in $1965 .{ }^{34}$ Justice Brennan would have applied the delegation doctrine in at least two cases, voting to strike down standardless grants of power to cabinet secretaries in areas affecting sensitive personal liberties. ${ }^{35}$ In the second of these cases, Justice Douglas (and apparently Justice Marshall) agreed that the grant of authority to the secretary was "too broad to pass constitutional muster," adding the following: ${ }^{36}$

This legislation is symptomatic of the slow eclipse of Congress by the mounting Executive power. The phenomenon is not brand new. It was reflected in Schechter Poultry Corp. \%. United States, 295 U.S. 495. United States 7. Robol, 389 U.S. 258, is a more recent example. National Cable Telerision Assn. \%. United States, 415 U.S. 336, and FPC 1. New England Pouter Co., 415 U.S. 345, are even more recent. These omnibus grants of power allow the Executive Branch to make the law as it chooses in violation of the teachings of Youngstown Sheet E Tube Co. \%. Sawyer, 343 U.S. 579, as well as Schechter, that lawmaking is a congressional, not an Executive, function.

Judge J. Skelly Wright, Professor Theodore Lowi, and others have also pointed to the vices of broad delegations and suggested that the delegation doctrine might be revived. ${ }^{37}$

These recent appearances of the delegation doctrine express an abiding concern that much major policy is no longer made by Congress, although under our constitutional system it should be. They suggest that if the courts fail to apply the delegation doctrine in order to correct this shift in the constitutional allocation of powers, they are abdicating their own constitutional function. They raise a question of increasing, not lessening, relevance for the future, in which greater economic planning at the national level is likely ${ }^{38}$ and the drift toward authoritarian executive policy-making may grow.

Whether it is wise to revive the delegation doctrine depends at least in

34. Zemel v. Rusk, 38 I U.S. I. 20 (1965). Cf. United States v. Sharpnack. 355 U.S. 286. 298-99 (1958) (Douglas, J., joined by Black, J., dissenting); and Justice Black's opinion in Youngstown Sheet \& Tube Co. v. Sawyer, 343 U.S. 579 (1952).

35. United States v. Robel, 389 U.S. 258, 269 (1967) (concurring in result) (Subversive Activities Control Act); California Bankers Association v. Schultz, 416 U.S. 21, $91-93$ (1974) (dissenting opinion) (Bank Secrecy Act): of. McGautha v. California, 402 U.S. 183, 248-87 (1971) (Brennan, J., dissenting). Justice Breman's delegation doctrine bears a close similarity to the void-for-vagueness doctrine.

36. California Bankers Association v. Schultz, 416 U.S. 21, 90-91 (1974) (dissenting opinion). In dissenting from the denial of certiorari in Mora v. McNamara. 389 U.S 934 (1967), a case challenging the lawfulness of our military operations in Vietnam, Justice Stewart (joined by Justice Douglas) explicitly noted (without "intimat[ing] . . even tentative views") that he wished to explore whether the Tonkin Gulf Resolution was a "constitutionally impermissible delegation of all or part of Congress' power to. declare war."

37. Wright, supra note 7, at 582-87: T. Low', supra note 22, at 146, 154-55 \& 297-99; Gellhorn \& Robinson, supra note 23, at 773, n.4 \& 774-79; Koslow, Standardless Administrative Adjudication, 22 AD. L. Rev. 407 (1970); Schotland. After 25 Years: We Come to Praise the APA and Not to Bury It, 24 Av. L. REv. 261, 263-64 (1972).

38. See, e.g., S.3050, 93d Cong.. 2d Sess. (1974) (proposed Balanced National Growth and Development Act); S.1795. 94th Cong., Ist Sess. (1975) (proposed Balanced Growth and Economic Planning Act). 
part upon the criteria which are developed for its application. A potentially crude doctrine, it needs to be refined, its use confined to relatively gross delegations. Considerable thought needs to be given to developing guidelines. Without pretending to be very exact or specific, let me suggest a few tentatively framed criteria:

(1) Congressional legislation delegating power to the executive or independent agencies should clearly state workable standards or intelligible principles to provide reasonable but genuine guidance for the act's administration.

(2) These standards or principles should resolve the major value questions under the act. Truly interstitial and minor policy-making-admittedly always a question of degree-and fact-finding to implement congressional value choices may be left to the administrator without constitutional problems. ${ }^{39}$

(3) The legislation may describe factors to be considered by the administrator, but reasonable and genuine guidance must be given concerning the relative weight of the various factors if the factors give little or no practical guidance by themselves.

(4) A requirement that Congress provide clear standards does not preclude Congress from providing a limited "safety valve" which permits exceptions in circumstances of demonstrated need. 4 "

(5) The existence of administrative standards interpreting a statute should not blunt a delegation challenge if the administrator has resolved a major policy issue which Congress itself did not resolve. Where the administrator makes major policy choices which Congress did not make, the burden is on the administrator to submit his standards to Congress for passage as amended legislation (subject to presidential veto). ${ }^{+1}$ Responsibility for these major policy

39. While the delegation doctrine should require that all major policy issues be resolved by Congress, Congress should not be required to legislate on as many policy details as it practically could. This requirement mighe lead to an unwise allocation of congressional resources, would eliminate a certain amount of necessary flexibility, and might be particularly difficult for courts to administer.

The text states an approach which turns on the nature of the issues unresolved by Congress. An alternative approach might look at congressional behavior, and apply the delegation doctrine only where Congress was faced with specific policy choices and sought to "pass the buck" or otherwise willfully abdicate its political responsibility. This "subjective" test, turning on the reasons for the delegation, would involve a judicially awkward inquiry into legislative motivation, would be difficult to apply, and would give the delegation doctrine a different scope than the approach suggested in the text. $C$. note 67 infra.

40. Cf. Leventhal, supra note 21, at 75-80. Congress should provide some principles to guide use of the safety valve: but, against the background of the statutes main standards, somewhat less congressional precision and somewhat greater administrative flexibility should be permitced for these narrow exemptions.

41. See note 129 infra for a brief discussion of legislation which requires the executive or agency to lay regulations before the Congress a specified time before the regulations become effective, and permits a resolution of one or both Houses to set the regulations aside without allowing a presidential veto. It would take another paper to discuss the complex constitutional and policy issues raised by such legislation and to consider fully whether, assuming its constitutionality, the existence of such a system of congressional oversight and review of executive action 
choices must be accepted by Congress-and accepted explicitly, not inferred from congressional silence or from congressional appropriations. ${ }^{42}$

(6) Specific necessities may justify otherwise impermissible delegations. For example, in a truly emergency situation, defined as one in which there is not enough time for Congress to lay down the basic policies, a broader than usual delegation to the President should be permitted. ${ }^{43}$ This approach is limited by its justification: If it is practical for Congress to grant more specific authority, it should be required.

Given the disfavored status of standardless delegations in the new regime, the courts might refuse to uphold even an emergency delegation unless, by its terms, the delegation expired after a short period of time; if the delegation is explicitly for a short period, and the President is required to return to Congress promptly for renewal of broad emergency authority or for more specific legislation, the emergency delegation should be less vulnerable. Furthermore, although considerable deference to the President is appropriate, the courts should be willing to look behind any presidential determination that emergency conditions actually exist which trigger his broad powers. ${ }^{44}$ Another necessity which may justify a broader than usual congressional delegation is where the effectiveness of a governmental decision requires that it be planned in secret. For example, the timing of a wage and price freeze has enormous distributional consequences and might otherwise be a decision that Congress

should be allowed to save an otherwise unlawful delegation from judicial invalidation. As a general matter, after the fact congressional oversight obviously mitigates some of the problems of broad delegations of major policy-making power. However, congressional oversight operates haphazardly since congressional scrutiny is not mandated. In the usual delegation situation, Congress is unwilling 10 assume responsibility for the policies in question, before or after the delegation takes place; for this and other reasons. many major executive policies would be allowed to continue in effect without Congress reviewing them on their merits and accepting responsibility for them. I do suggest at notes $43-45$ infra and accompanying text. that in rare cases a broad delegation might be permitted if Congress limits the duration of the delegation and thereby assures that whatever the executive or agency does will not continue for long without congressional review. See also notes 128-32 and accompanying text, and note $54 \mathrm{infra}$.

42. See notes $118-21 \mathrm{infra}$ and accompanying text for a discussion of when implicit congressional ratification of administrative action mat and may not be inferred.

43. Obviously, to the extent that the President may have inherent powers to act in certain emergency situations and not need congressional authorization at all, the delegation issue is irrelevant.

44. There are at least indications that courts will review the determinations of emergency or national security necessity. United States v. United States District Court, 407 U.S. 297 (1972); New York Times Co. v. United States, 403 U.S. 714.730 (1971); Youngstown Sheet \& Tube Co. v. Sawyer. supra note 1: Woods v. Cloyd W. Miller Co.. 333 U.S. 138, 144 (1948): Duncan 1. Kahanamoku, 327 U.S. 304,336 (1946) (Stone, C. J., concurring); Ex parte Milligan, 71 U.S. (4 Wall.) 2 (1866); Zweibon v. Mitchell, 516 F.2d 594 (D.C. Cir. 1975). rert. denied, 96 S. Ct. 1685 (1976); $c f .5$ U.S.C. $\$ 552$ (Supp. IV, 1974) (recent amendments to Freedom of Information Act authorizing court review of documents classification). But sep New York Times Co. v. United States, 403 U.S. at 757 (Harlan, J. dissenting); Sardino v. Federal Reserve Bank of New York, 361 F.2d 106 (2d Cir. 1966), cert. demied, 385 U.S. 898 (1966); United States v. Yoshida International Inc., 526 F.2d 560 (C.C.P.A. 1975). 
must make; but since the effectiveness of a freeze depends upon suddenness of implementation, the courts should not be troubled that the executive is given flexibility on the timing of the freeze, at least if some minimal congressional guidance is given. ${ }^{45}$ Here too, though, the delegation might be permissible only if it were of short duration.

There are, of course, numerous quite reasonable objections to the basic thrust of the delegation doctrine, whatever precise criteria for its application might be suggested. Many of these arguments rest upon the view that in practice congressional delegations serve useful purposes-indeed, that delegations are necessary. These arguments often ignore or dispute that basic constitutional values are at stake when Congress delegates large policy-making powers. The appeal of the arguments-however intuitive and speculative they may be-is that they seem to reflect obvious truths: that reality, including political reality, is extremely complex, and that there is no formula, particularly no constitutional formula, that can describe the way that government should go about the business of making wise policy. I agree, of course, that congressional delegations of relatively minor policy decisions are an essential part of modern government. My doubts concern the arguments defending delegations of major policy-making, which I think are weak-although certainly worth greater and more systematic investigation and evaluation than $I$ have yet undertaken. There can also be significant objections to the delegation doctrine because it invokes the courts to monitor congressional delegations. I turn now to a brief and tentative consideration of some of these criticisms of the delegation doctrine.

1. Professor Davis repeatedly says that the doctrine has "failed," and, as evidence, points to numerous cases in which the courts have upheld essentially standardless delegations. ${ }^{46}$ To a large extent, Davis is playing Holmes' "bad man"-simply predicting what the courts will do." And he is right in stating that lawyers who raise a delegation issue today are likely to lose. The modern precedents are overwhelmingly against the meaningful application of the delegation doctrine. If the doctrine is to be revived, litigants will have to appeal to basic constitutional principles and point to the fundamental change in our constitutional system that results from the continuing shift of power away from Congress and towards the executive and agencies.

2. The literature on delegation is full of statements to the effect that Congress is often too divided politically to set the kind of clear standards that the delegation doctrine envisions. ${ }^{48}$ Congress, in this view, is constrained to dele-

45. Cf. Amalgamated Meat Cutters v. Connally, $337 \mathrm{~F}$. Supp. at 752.

46. K. Davis, supra note $16, \S 2.01$ (1958 ed.), $\$$ 2.00-2.00-2 (1970 Supp.).

47. Look at the law, Holmes once advised law students, "as a bad man, who cares only for the material consequences which such knowledge [of the law] enables him to predict ...." Holmes, The Path of the Law, 10 HaRv. L. REv, 457, 459 (1897).

48. E.g., L. Jaffe, Judicial Control supra note 7 at 41 ; C. Summers \& H. Wellington, 
gate broad and vague powers as a means of resolving or avoiding policy disagreements. But, as Judge Wright suggests, this situation may be more an argument "for a vigorous reassertion of the delegation doctrine rather than against it." ${ }^{49}$ Fundamental policy conflicts do not go away when the legislature passes the buck; they are simply resolved by others, implicitly or explicitly. ${ }^{50}$ Why should Congress be allowed to abdicate the responsibility for making basic value choices for the society? Legal doctrine should provide Congress with an incentive to make these choices itself. If Congress cannot agree on what it wants to accomplish, and cannot hammer out an agreement on the basic policy choices involved in an area, then there probably should be no law.

Admittedly, such an approach might strengthen the hand of the status quo since certain legislation may become impossible to pass or may take longer to pass. This fact must be candidly faced and its impact on various social interests evaluated; but certainly a little less government regulation and a little less law are not necessarily bad things. Moreover, careful (if time consuming) legislative deliberations can be very useful in strengthening government action. Legislative policies carefully thought out in advance will probably be more effective in meeting needs. Clearly stated policies mean that Congress knows what it is doing, and the legislative commitment to change is likely to be more secure because it is more concrete. The more specific the legislative command the more likely the administrator will obey it. And as Lowi says, "A bureaucracy in the service of a strong and clear statute is more effective than ever." ${ }^{1}$ In any event, even if legislative lawmaking is generally rather slow, Congress can and does act with "expedition" in an emergency. ${ }^{52}$

Moreover, a notion that the executive and agencies will sidestep time consuming politics to act decisively and efficiently is often unrealistic. When Congress has difficulty making a policy decision it is usually because of the political forces, which will converge on the executive or agency if Congress does not resolve the issue. ${ }^{53}$ In fact this has happened, putting great pressures on the administrative process and producing backlog and delay.

3. A third argument is that Congress does not have the time or information to make policy, and therefore must delegate. ${ }^{54}$ But if Congress doesn't

Labor Law: Cases and Materials 237 (1969); Fisher, Delegating Power to the President, 19 J. Pub.

L. 25I, 26I-64 (1970); Stewart, supra note 7, at 1695-96.

49. Wright, supra note 7 , at 585 (emphasis added).

50. See Fisher, supra note 48, at 261 ("The hope of taking 'politics out of the tariff' . . was sorely disappointed"); Landis, supra note 23, at 55-56; T. LowI, supra note 22, at 126-27; Freedman, supra note 6, at 1054-55; Jaffe, The Illusion of the Ideal Administration, 86 HARv. L. REv. 1183 , $1189-90,1198(1973)$.

51. T. Lowi, supra note 22, at 298-99, 153-54. See also Freedman, supra note 6, at 1060.

52. Youngstown Sheet \& Tube Co. v. Sawyer, 343 U.S. at 653 (Jackson, J., concurring).

53. See Jaffe, supra note 50, at 1183,1190 , and other authorities cited in note 50, supra.

54. K. Davis, supra note $16, \S 2.00-3$, at 49 (1970 Supp.). Although post-delegation congressional oversight is sometimes viewed as preferable to congressional policy-making at the outset, it 
have time to focus in on the major policy issues concerning inflation, economic regulation, poverty, unemployment, energy, foreign trade and defense, it may be that Congress has chosen to spend too much time on less important things. When it chooses to do so, Congress clearly has the capacity to write far more detailed legislation than the delegation doctrine would ever require- $-g$. , in the tax area. ${ }^{55}$ Have the executive and agencies really demonstrated an inherent superiority in producing wise and coherent policy? Their so-called expertise has often failed us, both because administrative experts may not have the strength to prevail politically and because expert knowledge itself may not be advanced enough to solve certain problems. In any case, major policy issues involve value questions which should be decided in a broadly democratic way. Expertise, to be sure, is often an essential ingredient in clarifying and making value choices, but if Congress needs more information and staff expertise, it should get them for itself. Nor is there anything wrong with Congress' authorizing the executive or the agencies to do the background work and then to come to Congress with proposals; ${ }^{56}$ th is is far different from the executive and agencies making the ultimate decisions on policy. There is, admittedly, a limit to what can be expected in policymaking-whether by legislatures or the executive/agencies. Where value choices are intertwined with factual analysis requiring great expertise to develop and understand, it may be unrealistic to expect Congresspersons (or the President) ever to master the necessary details. In this circumstance, there is a dilemma: Either "experts" decide the important value questions with questionable legitimacy, or elected representatives make the value choices in the relative dark.

4. A related objection to the delegation doctrine is that "it may be impossible in the nature of the subject matter to specify with particularity the course to be followed. . . " 5 The short answer to this is that even if it may be impossible at times, it usually is not. There is wide agreement that Congress could do much, much better than it does in writing clear, specific statutes. ${ }^{58}$ More importantly, the delegation doctrine does not require that Congress necessarily concern itself with the details of "the course to be followed." (In-

goes without saying that oversight requires time and informed overseers if it is to be anything other than a haphazard and superficial effort. Criticism can be easier than creation; but if Congress does not have the time and information to decide upon policies before they are implemented, it is probably not in a position to undertake comprehensive and effective oversight after the policies are implemented either.

55. H. Friendly, supra note 7. at 163-75; T. Lowi, supra note 22, at 146, 154. 299: Freedman, supra note 6, at 1060; Jaffe, supra note 50, at $1183,1189-90$.

56. Congress recently followed a similar approach in a portion of the Energy Policy and Conservation Aci of 1975. Pub. L. No. 94-163, \$201(a)(b), 89 Stat. 871

57. Stewart supra note 7. at 1695. See also K. DAvis. supra note $16, \$ 2.00-3$ at 47 (1970 Supp.): C. Summers \& H. Wellngton, supa note 48, at 237: Sunshine Anthracite Coal Co. v. United States, 310 U.S. 381, 398 (1940); Butfield v. Stranahan, 192 U.S. 470, 496 (1904).

58. See note 55 supra. 
deed too many legislative details could hamper effective administration.) The delegation doctrine would be satisfied, and the present situation vastly improved, if Congress gave clear guidance on the major policy questions and conflicts under each statute, whether that guidance be in the form of standards, principles, or weighted factors. Where time, information, or "the nature of the subject matter" does not permit this much thinking through of the problem, how can Congress be convinced that governmental action or expenditure is even sensible, much less necessary? Having set the basic course, Congress can leave all truly interstitial policy-making, all the details, and all the administration to the executive or agency. If, after a period of living with the congressional choices, the administrator feels that they are unwise or unworkable, he can return to Congress, argue his case, and ask for a new law. ${ }^{59}$

5. One of the most difficult questions concerning the delegation doctrine is whether the judiciary can and should supervise the allocation of powers among the other branches in the way that the doctrine requires. ${ }^{60} \mathrm{~A}$ delegation challenge involves the setting of boundaries between the other branches, and such an effort raises problems often associated with so-called "political questions": Are there manageable judicial standards? Isn't a political resolution best? Is there too great a danger of confrontation with the orher branches? ${ }^{61}$ The shadow of a "political question," however, is always present when an issue is raised concerning the allocation of powers under the Constitution; as a general matter, it has not precluded the courts from playing the important and legitimate role described by Justice Frankfurter as "determining where authority lies as between the democratic forces in our scheme of

59. See Addison v. Holly Hill Fruit Products, 322 U.S. 607. 617 (1944). It may be said that full discretion should be left to the executive or agency since it can first proceed in an ad hoc fashion. learn about the field, gradually develop rules, and then secure more detailed legislation. Whether this is in fact an accurate description of what happens under most existing delegations is itself highly questionable. But, in any case, why should not the legislature be required to learn enough about a field before legislating so that it can provide at least basic principles and policies to guide the agency and its dealings with private parties from the beginning; poorly thought out regulation, after all, has victims. But $f$. L. Jaffe, Judicial Control of Administrative Action 38 (1965). As noted above, Congress, before authorizing regulation, can utilize executive expertise to learn whatcver it needs to know to develop reasonable standards and principles. In any event. reliance on administrative experimentation at most justifies delegations of only limited duration.

60. Stewart, supra note 7 , at $1696-97$.

61. As summarized in Baker v. Carr, 369 U.S. 186, 217 (1962), an issue may become a "political question" when there is:

a textually demonstrable constitutional commitment of the issue to a coordinate political department; or a lack of judicially discoverable and manageable standards for resolving it; or the impossibility of deciding without an initial policy determination of a kind clearly for nonjudicial discretion; or the impossibility of a courts undertaking indepen. dent resolution without expressing lack of the respect due coordinate branches of government; or an unusual need for unquestioning adherence to a political decision already made; or the potentiality of embarrassment from multifarious pronouncements by various deparments on onc question.

See also Powell v. McCormack, 395 U.S. 486 (1969). 
government." 62 The issues may be important in the political process, but they involve fundamental questions of law as well. Thus, the courts have struck down statutes on delegation grounds in the past, and even when they have rejected delegation challenges, they have invoked the usual formulas and never doubted that the delegation doctrine was properly for judges to apply.

Nevertheless, the appropriateness of the judicial role may be questioned. One very significant problem is that it may be difficult for judges to apply criteria for determining whether an improper delegation has occurred. "When," Alexander Bickel asked, "should the Court recall the legislature to its own policy-making function? Obviously, the answer must lie in the importance of the decision left to the administrator or other official." 63 This may not be the complete or only "answer," 64 but it is obviously a significant part of the answer, and a potentially difficult one to apply. Where the delegated decision affects the constitutional rights of individuals, there is at least a ready benchmark for assessing the "importance" of the powers delegated. But in other situations, how is the court to determine whether the policy-making powers delegated to the executive or agency are too great-i.e., that the policy questions that are left to the administrator are sufficiently major, or novel, or controversial, or have such a wide impact, that they should have been resolved by Congress. ${ }^{65}$ The legislative history may provide some help-by highlighting the various (unresolved) policy issues in an area that persons in and before Congress felt were of fundamental importance-but the court may be faced with difficult judgments. Admittedly, the line between fundamental policy-making (which is for Congress), and minor or interstitial policy-making (which may be left to the executive and agencies) is a somewhat blurry and subjective one-but is it significantly more so than the lines that courts often draw and work around?66 Certainly in many cases-the gross cases to which

62. Youngstown Sheet \& Tube Co. v. Sawyer, 343 U.S. at 597 (concurring opinion). In addition to Youngstown. some leading cases involving the allocation of powers within the national government are Humphrey's Executor v. United States, 295 U.S. 602 (1935) (Congress may limit President's power to remove officials of independent regulatory commissions); Myers $v$. United States, 272 U.S. 52 (1926) (Congress has no power to limit President's removal of executive officials); United States v. Klein, 80 U.S. (13 Wall.) 128 (1871) (President's pardoning power); Kendall v. United States $e x$ rel. Stokes, 37 U.S. (12 Pet.) 524 (1838) (impoundment); $c f$. Hayburn's Case, 20 U.S. (2 Dall.) 409 (1872) (judicial exercise of executive functions). Cases involving the allocation of powers between the national government and the states in our federal system have historically, of course, been among the most important and numerous on the Supreme Court's docket; see generally G. Gunther, Constitutional Law: Cases and Materials 81-401 (9th ed. 1975).

63. A. BiCKel, supra note 7 , at 161 .

64. See note 39 supra and accompanying text to notes $39-45$

65. Professor Bickel himself apparently believed that courts may properly "recall the legislature to its own policy-making function" where non-constitutional policies are involved. A. BICKEL, supra note 7 , at 161 . See note 122 infra.

66. In fact, the courts distinguish major from interstitial lawmaking all the time because a similar distinction is one that generally marks the boundaries of the judiciary's own power to 
the delegation doctrine is primarily addressed-the courts should have little difficulty in determining that the most basic issues were left to the executive or agency to resolve.

Why, it may be asked, is it appropriate for the judiciary to protect congressional policy-making powers where Congress itself has clearly and explicitly agreed to the loss of those powers? In fact, it is this very willingness of Congress to go along that may make judicial intervention necessary. Congress has agreed to a fundamental shift in power among the branches which is transforming our constitutional system. The courts are traditionally willing to step in when Congress acts against enduring constitutional values, and in doing so the courts perform an accepted judicial function. ${ }^{67}$ The very absence of an active boundary dispute among the branches when Congress transfers great powers means that there is no prospect of a political resolution consistent with our constitutional principles-and therefore judicial intervention may be particularly appropriate. Nor is there a messy inter-branch struggle that might justifiably lead courts to stay their hand. ${ }^{68}$

The great modern expansion of presidential power, with its attendant risk, may legitimate a somewhat more active judicial role to protect against that

interpret statutes and make law. See Frankfurter, Some Reflections on the Reading of Statutes, 47 Colum. L. Rev. 527, 534 (1947); Guiseppi v. Walling, 144 F.2d 608, 620-22 (2d Cir. 1944), aff $d$, 324 U.S. 244 (1945). For various examples of where the courts have assessed the importance of policies and interests-and where they have refused-see notes 112-16. 126 infra and accompanying text.

67. My basic argument is that a judicially applied delegation doctrine is appropriate and within the traditional universe of judicial review because congressional delegations of major policy-making powers offend fundamental constitutional principles. In applying these basic principles, it is not necessary for courts to undertake what would be a more problematic effort of evaluating whether delegations in particular cases do or do not promote the making of wise policy. The courts obviously have no particular institutional competence to make at large judgments about the best way to make policy.

To be sure, $I$ also argue that $I$ see no overriding prudential reasons to abandon fundamental principles and permit broad delegations. And I have also suggested that delegations of major policy-making power do not usually reflect a considered congressional judgment about how wise policy should be made, but simply involve an avoidance of political and constitutional responsibility. On these assumptions, a judicially enforced, essentially blanket rule against major delegations is most readily defensible. If Congress were to dispute these general assumptions in particular cases-for example, by making a specific determination that a particular delegation were necessary because certain characteristics of the policy area favored an incremental administrative development of policy-the picture would become more complicated, although constitutional objections would still be possible. As noted at note 39, supra, the courts might conceivably try to accommodate certain delegations by developing a "subjective" test which turns on the motive (or even the necessity) for each delegation that is challenged. The next section of this paper, notes 74-131 and accompanying text describes another, and, I believe, preferable approach that would, in essence, regulate congressional delegations of power only to the extent of trying to assure that they reflect Congress' considered judgment: Major executive policy-making would be permitted provided that the statutory authorization for it is clearly and explictly expressed.

68. Admittedly, since both political branches will generally have concurred in the delegation there may in theory be a greater than usual chance of united political opposition to a court order striking down a statute on delegation grounds. 
power. ${ }^{69}$ While the delegation doctrine certainly thrusts the courts into the political process, it is less intrusive than most judicial review because it does not limit the power of the federal government to take action; rather, it concerns the method of exercising that power. Since the only issue is which branch must act, the question is not what the federal government may do, but in what way. ${ }^{70}$

1 will return to these and related questions concerning the nature and propriety of the judicial role in recalling Congress to its policy-making function. But for now I rest with the words of Learned Hand, who generally believed in the most sparing use of the power of judicial review: ${ }^{11}$

It is of course true that when a court holds that a legislature has left too much latitude to an administrative tribunal, it overrules a decision of the legislature as to its powers; but there appears to me a tenable distinction between that situation and one where a court overrules the actual exercise of legislative authority; for the delegation of authority is pro tanto the abdication of authority over the subject matter by a transfer to others of authority that the legislature alone may exercise. Once we assume that courts are to set the boundaries of each "Department's" authority, it follows that they must say where legislation begins, however hazy its boundaries may be.

In sum, then, the delegation doctrine may have greater use than generally believed, at least where quite gross delegations are made. The doctrine is admittedly a rather rough weapon-voiding a statute; temporarily at least, preventing action in an area of presumptive importance and flatly forbidding anyone but Congress from ultimately deciding what action to take. It is also a limited weapon because it cannot force Congress to act. ${ }^{72}$ But because of the sharpness of the sanction, it may well be an effective deterrent to congressional abdication of responsibility. It may also give Congress a good excuse

69. Cf. Cox, Executive Privilege, 122 U. PA. L. REv. 1383, 1433-34 (1974).

70. Cf. A. BICKel, supra note 7 , at 161. The two grounds for striking down the NIRA in Schechter Poultry, supra note 14, illustrate this distinction. The Court held that the statute impermissibly delegated power, but also held that the federal government exceeded its power under the commerce clause. (Indeed, the decline of the delegation doctrine may be partially explained by the post-1935 rush of the Supreme Court to legitimate the exercise of national power under the commerce clause. In this period, the two doctrines relied upon in Schechter may have been linked together and therefore discredited together, even though the delegation doctrine need not have interfered with the continuing development of broad national powers.)

Lowi notes that instead of striking down broad, standardless statutes, the courts often "legislate" by supplying standards. "A blanket invalidation under the Schechter rule is a Court order for Congress to do its own work. Therefore the rule of law is a restraint upon rather than an expansion of the judicial function." T. Lowr, supra note 22, at 298. As noted at note 51 supra and accompanying text, the delegation doctrine might operate to strengthen the hand of the status quo since it would interpose the courts against major executive/administrative policies not endorsed by Congress. While this highlights the fact that the doctrine's effect might not be neutral with respect to those social interests seeking one or another governmental action, the critical point here is that in invoking the delegation doctrine the courts are not substantive value choosers.

71. L. Hand, The Bill of Rights 49 (1958).

72. Cf. Youngstown Sheet \& Tube Co. v. Sawyer, 343 U.S. at 654 (Jackson, J., concurring). 
for resisting pressure when the executive seeks legislation giving it broad discretionary power. And it may infuse into the political process a constitutional principle of congressional responsibility for policy-making, which, because it is articulated by the courts as principle, might become a norm for behavior; this, after all, is the highest promise of judicial review. There is no guarantee, of course, that it would do any of these presumably beneficial things.

III

\section{The Uses of Statutory Construction}

The delegation doctrine seeks to curb executive and agency lawmaking and to protect and strengthen Congress' article I power by direct application of constitutional law, striking down statutes which cede too much policymaking power to the executive. A more modest and, in my view, preferable weapon in the service of the same constitutional principle is available through statutory interpretation.

Statutory interpretation is a neglected field in legal scholarship; we lack a fully developed, modern theory of the judicial role in interpreting statutes ${ }^{73}$ Such a theory, of course, would inquire into the various ways courts identify legislative purpose by examining text, legislative history, etc. But it would also identify, evaluate and propose policies, external to the legislative purpose identified from text and immediate context, which enter into the judicial activity of interpretation-policies which shape the meaning given to a statute even where those policies cut somewhat against the legislative purpose narrowly defined. That such external policies (sometimes embodied in so-called canons or principles of statutory construction) do influence the construction given statutes cannot be doubted; and, as noted below, they have influenced the judicial interpretation of congressional statutes delegating power to the executive and agencies. My objective in this portion of the paper is obviously not to develop a general interpretive theory, but simply to suggest the possible role of a rather different external policy to guide judicial interpretation of this single category of statutes.

\section{A. A Clear Statement Approach to Major Executive and} Agency Actions Requiring Statutory Authorization

The flow of policy-making power from Congress to the executive and the agencies has been helped along by the willingness of the courts to interpret

73. The best general writings on the subject of statutory interpretation with which I am familiar are H. Hart \& A. Sacks. The Legal Process (tent. ed. 1958): H. Friendly. Mr. Justice Frankfurter and the Reading of Statutes, in BENCHMARks 196 (1967); and Frankfurter, supra note 66. Harry Wellington's and Alexander Bickel's writings-usually on broader or narrower subjectsalso contain many useful and provocative observations; see note 7 supra and notes 78, 97, 111 infra. 
generally phrased or ambiguous congressional statutes as conferring on the executive and the agencies the power to make important and sensitive policies. Examples exist in widely disparate areas. The Supreme Court has permitted the President to use certain unusual statutory war powers well after hostilities had stopped, even though the authorizing statutes did not clearly permit this. Ludecke v. Watkins, 335 U.S. 160 (1948). The Court has permitted the Secretary of the Interior to exercise extraordinary powers to allocate water in the entire southwest region using his own formula rather than established equitable principles, even though he was not clearly authorized to do so. Arizona \%. California, 373 U.S. 546 (1963). The Supreme Court has permitted the Federal Communications Commission to regulate cable television broadly even though the statute supposedly authorizing such regulation was phrased very generally, was passed before the invention of cable television and was premised upon technological characteristics of radio and television not shared by cable television. United States \%. Southwestern Cable Co., 392 U.S. 157 (1968); United States ข. Miduest Video Corp., 406 U.S. 649 (1972).

In the ordinary case, statutory authority for a challenged executive or agency action may properly be found by implication, and courts will employ a policy giving considerable deference to the administrator's interpretation of the scope of his powers. ${ }^{74}$ But where the executive or agency claims the statutory authority to make major policy, the courts, I believe, should probably take a different approach, requiring greater than usual explicitness and specificity from Congress itself before permitting the executive to act. This approach reflects the view that in our constitutional system major executive policy-making is disfavored and bears a burden of justification.

Recognizing that principles of statutory construction are rarely dispositive in deciding concrete cases, ${ }^{75}$ let me suggest one: Statutes should not be construed as permitting the executive or agencies to make major policy decisions that are within Congress' article I powers, unless Congress has clearly and specifically said so. Put another way, where it is not clear that a statute authorizes an executive or agency decision of major significance, the courts should construe the statute narrowly, and, in effect, require Congress' specific authorization. This approach is implicit in a number of cases limiting the au-

74. E.g., Investment Company Institute v. Camp. 401 U.S. 617, 626-27 (1971); Red Lion Broadcasting Co. v. F.C.C., 395 U.S. 367, 381 (1969); Zemel v. Rusk, 381 U.S. 1, $11-12$ (1965); Udall v. Tallman, 380 U.S. 1, 16 (1965); United States v. Jackson, 280 U.S. 183,193 (1930); E. Corwin, The President: Office and Powers 120, 389 n.l (4th ed. 1957). Much of this deference appears to rest on the presumed expertise of those who administer the law. In spite of this deference, the courts have also made clear that questions of law are for the judiciary to resolve and that an administrative interpretation will not be upheld where it is inconsistent with the statute. Volkswagenwerk v. FMC. 390 U.S. 261, 272 (1968); American Ship Building Co. v. NLRB, 380 U.S. 300,318 (1965).

75. See K. Llewellyn. The Common Law Tradition 521 (1960); Frankfurter, supra note 66 , at 544 
thority of the executive and agencies, but has not, I believe, been articulated or applied with full explicitness. ${ }^{76}$

Like other principles of statutory interpretation to be discussed below, this clear statement doctrine counsels that statutory construction "should go in the direction of constitutional policy"77-here, the constitutional policy that lawmaking of major significance is generally Congress' business. The doctrine could function in two main ways. First, and most importantly, where the congressional purpose is truly ambiguous, a statute would be interpreted as not authorizing the executive and agencies to take major policy steps. Second, where Congress has granted broad general authority to the executive and agencies, arguably reaching the major executive or agency action in question, the authority to act may still be denied; here the clear statement approach, like other doctrines of statutory construction, admittedly may resist the congressional purpose somewhat, in the interests of an underlying principle in our constitutional system. ${ }^{78}$ The clear statement doctrine says to Congress: Given your constitutional role under article I, we will not lightly assume that you really meant to authorize the executive or agency to make this large decision on its own; we encourage your direct participation in this decision, but, at a minimum, before the executive or agency may assume the specific powers in question, you must deliberate about whether that course is appropriate ${ }^{79}$ and authorize it more clearly and explicitly than you have already done. The clear statement approach is designed to encourage the executive and agencies to go to Congress with large policy questions and to share decision making. It curbs certain executive and agency lawmaking, and invites (even pressures) Congress to resolve the policy issue itself. But Congress is allowed to decline the invitation, for the clear statement doctrine does not oppose executive/agency policy-making if and when Congress clearly and specifically authorizes it.

This approach can be illustrated by the court of appeals' decision in Algonquin SNG, Inc. \%. Federal Energy Administration, subsequently reversed by the Supreme Court. ${ }^{81}$ The case involved the lawfulness of President Ford's controversial imposition of sharply increased oil import license fees in early 1975 ,

76. Joseph Sax has proposed that courts intervene to prevent major environmental actions not clearly authorized by Congress; the burden of obtaining such authorization would then be on the proponents of the project. J. Sax, Defending the Environment: A Strategy for Citizens Action (1971). Richard Stewart has noted that this proposal might be broadened, but that it would be impractical. Stewart, supra note 7, at 1788-89.

77. See, e.g., Regional Rail Reorganization Act Cases, 419 U.S. 102, 134 (1974).

78. See Wellington, Common Law Rules and Constitutional Double Standards: Some Notes on Adjudication, 83 Y ALE L.J. 221, 264 (1973).

79. To borrow Justice Stone's phrase and say that Congress is required to give the question "sober second thought," Sione, The Common Law in the United States, 50 Harv. L. Rev. 4, 25, might overstate what Congress has already done; often Congress could not be said to have given any thought at all, one way or the other, to whether the executive or agency should exercise the specific policy-making power claimed.

80. 518 F.2d 1051 (D.C. Cir. 1975), rev'd, 96 S. Ct. 2295 (1976). 
an action which was "an important part of the President's energy program." 1 The license fees were imposed pursuant to 19 U.S.C. $\S 1862$ (b) (Supp. IV, 1974) (Section 232(b) of the Trade Expansion Act of 1962, as amended), which authorizes the President to "take such action, and for such time, as he deems necessary to adjust the imports of [an] article and its derivatives so that ... imports [of such article] will not threaten to impair the national security . . . ."82 The United States Court of Appeals for the District of Columbia, one judge dissenting, held that $\S 1862(\mathrm{~b})$ only delegated to the President authority to adjust imports through direct mechanisms (a quota), but not through the indirect mechanism of an import fee. Thus, in spite of the background of "energy crisis," the court struck down the President's action. Although the broad statute on its face seems to give the President comprehensive powers, and the legislative history, in my view, tilts very slightly toward authority for a fee ${ }^{83}$ the court of appeals' result was correct.

The court of appeals rejected "the expansive statutory construction" advanced by the President and construed the statute narrowly to protect Congress' power to make trade policy from executive encroachment. "The arena for [the] debate over trade policy," the court said, "has been Congress," and "the Government's interpretation of section 1862(b) would represent an anomalous delegation of almost unbridled discretion and authority in the tariff area." ${ }^{84}$ Moreover, the "magnitude" of the import fees at issue here was enormous and the "assertion of executive authority" was "massive." 85 (The import fees involved would have doubled the annual tariff revenue of the United States.) Thus, the court applied what it called "careful scrutiny" 86 and read the statute narrowly in spite of its apparent breadth. Because trade policy and tariffs have been Congress' business and imposition of the import fees here was a major trade policy action, the court required (but did not find) clear and specific congressional authorization for what the President had done. ${ }^{87}$ Although the court of appeals did not quite say so, this is the method

81. The quotation is from the unreported district court opinion upholding the President, attached as an appendix to the court of appeals opinion, 518 F.2d at 1066.

82. Section 1862(c) enumerates various "relevant factors" to be considered by the Secretary of the Treasury and the President in making the "national security" determination, and as the court noted, "the umbrella of national security" here is very broad indeed. $518 \mathrm{~F} .2 \mathrm{~d}$ at 1066.

83. Compare the court of appeals" discussion of the legislative history, 518 F.2d at 1056-60, with that by the Supreme Court, $96 \mathrm{~S}$. Ct. at 2303-07 and in the Governments Petition for Certiorari. pp. 11-16, filed on September 10, 1975.

84. 518 F.2d at 1056 .

85. Id. at 1052,1056 .

86. Id. at 1056 .

87. The court did not reach, inter alia, the argument that the statute should be narrowly construed in order to avoid an unconstitutional delegation. $518 \mathrm{~F} .2 \mathrm{~d}$ at 1055.1062 ; see note 32 supra and note 89 infra. But the court was at pains to emphasize that the government had ample power to act provided that an appropriate statute was passed. $518 \mathrm{~F} .2 \mathrm{~d}$ at 1062 . The court then added: 


\section{of clear statement that 1 have suggested.}

There was, of course, more at stake here than an issue of "trade policy." What the President had done, as the district court acknowledged, was to respond to a newly perceived and long-term peacetime energy crisis by trying to put in place a major, long range and controversial energy program-"the President's energy program"-without congressional approval. But energy policy in our political system is supposed to be made by Congress, or at least with Congress, not unilaterally by the President. The President should not be permitted to institute a major peacetime energy program-at least (a clear statement approach suggests) not unless Congress clearly has delegated energy policy discretion, which Congress had not done. ${ }^{88}$ Thus, whether viewed as an energy policy or trade policy case, the court of appeals in Algonquin SNG properly held that the President lacked the authority to impose this import fee program. The method of clear statement "sends" the matter "back" to Congress, where it belongs. ${ }^{89}$

More fundamentally, this case raises a question about the way Government should operate when responding to crisis. Neither the term "national security" nor "emergency" is a talisman, the thaumaturgic invocation of which should, ipso facto, suspend the normal checks and balances on each branch of Government. Our laws were not established merely to be followed only when times are tranquil. If our system is to survive, we must repond to even the most difficult of problems in a manner consistent with the limitations placed upon the Congress, the President, and the Courts by our Constitution and our laws. We believe we reaffirm that basic principle today. 518 F.2d at 1062 .

88. Viewed in this light, the nature of the narrow construction adopted might have been different. What was problematic about the President's action was not so much that it was an "indirect" adjustment of imports rather than a "direct" adjustment, but that this particular indirect adjustment was such an unusual one, so massive a response to a newly perceived problem, so controversial, and of such major significance to the country and its long-term energy future. While the line between "direct" and "indirect" adjustments is sharp and fairly objective, and separates approaches with distinguishable economic effects, perhaps the court of appeals should have focused decisively on the particular fee involved and interpreted the statute as simply not authorizing an indirect fee of this unusual kind and purpose. Arguably, perhaps, even if a controversial, long-range energy policy initiative had been implemented by means of a direct reduction in imports, an import reduction of this kind should have required more specific congressional authorization than $\$ 1862$ provided.

89. The Supreme Court's decision, 96 S. Ct. 2295 (1976), handed down after this paper was prepared and delivered, upheld the President's power to impose the tariffs. Whereas the court of appeals had applied "careful scrutiny" and narrowly construed the statute in question, the Supreme Court read the statute in the expansive spirit that has characterized most of its decisions interpreting congressional delegations to the executive. As indicated in note 32 supra, the Supreme Court first held that there was no need to construe the statute narrowly to avoid an unconstitutional delegation of congressional power. Then the Court held that the language of the statute and the legislative history each supported the President's view that the authorization to "adjust imports" encompassed the imposition of the license fees involved here as well as import quotas. The Court did not mention that foreign trade policy and tariff authorizations have traditionally been jealously guarded by Congress through narrow and explicit delegations, that the tariffs here were massive, that the tariffs were the centerpiece of a new and major national energy policy, or that any other factors were present suggesting that the statute should be narrowly construed and that clearer and more specific congressional authorization should be required before the President could act. Nor did the Court give any other signs that it understood 
In each of my first three examples, a requirement of clear statement would have led to a different result. In Ludecke $\%$ Watkins, the President's extraordinary statutory war powers would be deemed to terminate when hostilities ended rather than when a peace treaty was signed, since Congress had not clearly authorized his unusual power for the longer duration. ${ }^{90}$ In Arizona v. California, the Secretary of the Interior would be required to use established equitable principles for allocating the waters rather than his own formula, because Congress had not clearly granted him the authority to develop his own policies. ${ }^{91}$ Finally, the Federal Communications Commission would not be permitted to regulate cable television under its general "public interest" duties, because the regulation of cable television is a major policy initiative not clearly and specifically authorized by Congress. ${ }^{92}$

The Nixon impoundment cases also reflect, or can be viewed to reflect, a clear statement approach. The cases generally held that the statutes under which the President sought to impound funds were mandatory statutes, leaving the President no discretion to withhold funds for reasons collateral to the program's purposes, such as saving money. ${ }^{93}$ The statutes and appropriations bills, it is fair to say, were not always as apparently mandatory as the courts suggested. But the courts seemed to be guided by a presumption that the claimed impounding power did not exist under the statutes, and this is really

that a relatively major allocation of powers issue was at stake here. In short, it viewed this case as one raising simply an ordinary issue of statutory construction. Compare the subtle opinion of Justice Stevens for the court in Hampton v. Mow Sun Wong, 96 S. Ct. 1895 (1976).

90. See 335 U.S. at 173 (Black, J., dissenting). The result in Woods $v$, Cloyd W. Miller Co. 333 U.S. 138 (1948) would be unchanged. There, Congress had specifically determined to extend wartime rent controls into the post-war period and there was a reasonable basis for Congress exercising its powers to do so.

91. See 373 U.S. at 603, 624-27 (Harlan, J., dissenting).

92. See United States v. Midwest Video Corp., 406 U.S. at 677, 681 (Douglas, J., dissenting) ("Congress is the agency to make the decision and Congress has not acted. . . [T] legislative measure so extreme that we should not find it interstitially authorized in the vague language of the Act.").

Such an approach was followed recently in Accuracy in Media, Inc. v. F.C.C., 521 F.2d 288 (D.C. Cir. 1975), cert. denied, 425 U.S. 934 (1976), holding that the FCC could not assert jurisdiction over the Corporation for Public Broadcasting "absent a clear [congressional] statement to that effect."

93. E.g., Train v. City of New York, 420 U.S. 35 (1975) (allotment stage); Sioux Valley Empire Electric Assin v. Butz, 504 F.2d 168 (8th Cir. 1974); State Highway Commission r. Volpe, 479 F.2d 1099 (8th Cir. 1973); Guadamuz v. Ash, 368 F. Supp. 1233 (D.D.C. 1973); Pennsylvania v. Weinberger, 367 F. Supp. 1378 (D.D.C. 1973) (allotment stage); National Council of Community Mental Health Centers v. Weinberger, 361 F. Supp. 897 (D.D.C. 1973). But cf. Pennsylvania v. Lynn, 501 F.2d 848 (D.C. Cir. 1974), discussed in note 96, infra; Housing Authority v. HUD, 340 F. Supp. 654 (N.D. Cal. 1972). Claims that the executive had a constitutional right to impound were made, but uniformly rejected. The courts largely relied upon Kendall v. United States ex rel. Stokes, 37 U.S. (12 Pet.) 524 (1838), which held, on rather unusual facts, that the executive had no power to refuse to spend mandated appropriations. The constitutional issue was apparently not raised in Train v. City of New York, supra, the only Supreme Court case to consider the Nixon impoundments. 
an expression of clear statement principles. ${ }^{94}$ The President's claim that the statutes permitted him to impound funds for non-program related reasons was effectively a claim of major policy-making powers, and would directly encroach upon and dilute Congress' article I policy-making powers. The clear statement doctrine says that congressional statutes will not be deemed to cede such policy-making power unless Congress has clearly said so. ${ }^{95}$ Even if ambiguous hints could be found that the statutes left the President with the impounding discretion that he claimed, Congress certainly had not indicated with appropriate clarity that it meant to grant this very significant power. ${ }^{96}$

The clear statement approach is related to the delegation doctrine in that it is designed to curb executive and agency discretion and require policymaking by Congress. Each prevents a particular executive policy from being effectuated. Each protects Congress' article I powers. In many situations, either doctrine could be used. (Indeed, where Congress delegates broad general powers without mandating a congressional policy, the courts could invoke

94. E.g., State Highway Commission v. Volpe, 479 F.2d at 1111,1114 ; Pennsylvania v. Weinberger, 367 F. Supp. at 1381: Guadamuz v. Ash, 368 F. Supp. at 1241. See generally Note, Impoundment of Funds, 86 HARv. L. REv. 1505, 1527 (1973); Note, Protecting the Fisc: Executive Impoundment and Congressional Powers, 82 YALE L.J. 1636 (1973).

95. A decision by prosecutors and police not to investigate and enforce certain laws or to spend relatively little of their limited time and budget on investigation and enforcement of certain laws raises issues similar to executive impoundments. However, prosecutorial discretion is a complex and rather specialized problem, and prosecutorial decisions not to enforce the criminal laws are usually insulated from judicial review under the prevailing view (e.g., Linda R.S. v. Richard D., 410 U.S. 614 (1973)). The entire subject needs fuller treatment than I can provide here.

96. Pennsylvania v. Lynn, 501 F.2d 848 (D.C. Cir. 1974) is an extremely interesting exception to the general drift of impoundment cases, but passage of the Congressional Budget and Impoundment Control Act of 1974, Pub. L. No. 93-344, 88 Stat. 297, has probably limited its practical importance. The Court held that the Secretary of HUD had the power to suspend various housing programs "when he has adequate reason to believe that they are not serving Congress' purpose ... or are frustrating the national housing policies. . ." 501 F.2d at 855-56. In determining that the Secretary had such authority, the Court did not (even implicitly) use a clear statement approach, apparently believing that a suspension for the stated purposes would effectuate congressional housing program policies, unlike the other impoundments which had effectuated the executive's non-program related policies. The court then went on to conduct an extraordinary analysis of the available facts about the programs, and decermined that their operation actually did frustrate congressional housing policies and that the Secretary had sufficient reason to believe that this was caused by the programs' intrinsic structure, rather than the way they were administered. In my view, the Secretary's judgment that the programs were not "working" was a policy judgment that Congress might well have opposed, and the Secretary's decision that the programs inherently couldn't be made to work was a major policy judgment clearly in direct conflict with Congress' judgment when it passed the statute. Because the Secretary' judgments affected the expenditure of billions of dollars, he should have been required to seek congressional repeal rather than suspend the program on his own, particularly because there was no emergency that made it impossible to go to Congress. The Congressional Budget and Impoundment Control Act of 1974, now in effect, either would have required the Secretary to seek congressional approval for a "rescission" of the funds or, arguably, would have permitted him to "defer" expenditure of funds until the last year of the authorization, unless one or both houses passed a deferral resolution setting aside the Secretary's action. 
the traditional principle of construing the statute narrowly to avoid constitutional doubts about the delegation. ${ }^{97}$ This approach was followed by the Supreme Court in the National Cable Television case.) ${ }^{98}$

But while the delegation and clear statement doctrines may overlap, the two approaches are significantly different. Clear statement is a finer weapon. It does not invalidate a statute but simply reads it narrowly to preclude specific executive or agency action; a core of legislation is left intact. It potentially has more uses than the delegation doctrine because it can be invoked to limit executive or agency initiatives under statutes that do have constitutionally adequate standards but which do not clearly authorize the action in question. The clear statement approach might also be used with respect to statutes that have already been upheld as constitutional delegations but really provided no congressional guidance; triggered by an expansive new claim of power outside the established core of the administrator's authority, a narrow construction could cause congressional reexamination of the statute's broad, general mandate. ${ }^{99}$

The most important difference is that clear statement is simply a doctrine of statutory interpretation, not constitutional law, and therefore any court decision applying it may be overridden by the legislature. The delegation doctrine says to the legislature that it may not delegate the policy-making function at all. The clear statement approach simply tells the legislature that if it wants to abdicate its policy-making responsibility it must do so clearly, but that if it really wishes to do so, it may. The delegation doctrine flatly precludes an executive or agency decision of the major policy question; the clear statement doctrine leaves Congress free to decide that the executive or agency should decide, provided that Congress focuses in on the matter and speaks clearly and explicitly about its intentions. Application of the delegation doctrine runs a risk of sorts. If the legislature becomes stymied, it is not permitted to pass the buck; governmental inaction is at least conceivable in a situation where government action is admittedly essential. But clear statement invokes princi-

97. The doctrine of narrow construction to avoid constitutional doubts is essentially a doctrine of judicial restraint, a device for avoiding the uniquely sensitive deliberations and potential sanctions of a constitutional judgment. Its use should be premised on at least good faith doubts about a statute's constitutionality. In fact, it is often used to salvage a statute that the court believes it would otherwise have to strike down. See, e.g., United States v. National Dairy Products Corp., 372 U.S. 29, 32 (1963); International Ass'n of Machinists v. Street. 367 U.S. 740,749 (1961); Crowell v. Benson, 285 U.S. 22. 62 (1932); and Yamataya v. Fisher, 189 U.S. 86, 101 (1903). See generally Wellington, Machinists is Street: Statutory Interpretation and the Avoidance of Constitutional Issues, 1961 Sup. CT. REv. 49. It obviously could not properly be used in this context unless the delegation doctrine has considerable constitutional life.

98. See note 32 supra and accompanying text.

99. See Stewart, supra note 7, at 1697. Southwestern Cable and Miduest Video, discussed at notes 74 and 92 supra and accompanying text. 74. 88 supra provided such an opportunity in the communications area; but the Court continued to permit expansive application of the Communications Act of 1934 . 
ple more tentatively. The court reminds the legislature that it is supposed to make major policy, and tries to encourage that result; but if the legislature, by simple majority, expressly defers to the executive anyway, the court will stand aside. ${ }^{100}$ These differences may make the clear statement approach a preferable tool for accommodating a concern about unbridled executive/administrative power and a perception that the public interest may require significant executive/administrative policy-making in some circumstances.

Various doctrines of clear statement and narrow construction have an honorable tradition in our law, and in most of their applications they reaffirm the legislature's dominant role as lawmaker in the face of some executive or agency action. ${ }^{101}$ The doctrines have generally been applied when individual liberties are at stake, with constitutional policies at least somewhere in the background. But this has not always been so. In any event, the case law provides at least close analogies for the suggestion that a clear statement approach be applied to major policy actions of all sorts undertaken by the executive and agencies.

Criminal statutes, of course, are narrowly construed under a doctrine of clear statement. ${ }^{102}$ While one purpose of the doctrine is 10 assure that citizens have "fair warning," 103 another is to assure that the legislature, and not prosecutors and the courts, define criminal conduct." ${ }^{114}$ The reason for this institutional concern that the legislature decide is, in part, "because of the seriousness of criminal penalties." ${ }^{105}$ In other words, because of the social importance of the criminal law, we do not permit the executive (prosecutor) to charge crimes not clearly authorized by the legislature.

100. There might, of course, be various strong and weak versions of a clear statement rule. requiring different degrees of clarity and specificity from Congress. Under the strongest version. a court might refuse to find the requisite clarity unless Congress canc close to making the policy decision itself. Here the effect of the doctrince is not simply to remind Congress of its policymaking function. but really to insist that it be exercised-and the clear statement approach comes close to merging with the delegation doctrine.

101. The account that follows is obviously selective. For example. I do not discuss one of the most traditional clear statement doctrines. the rule that statutes in derogation of the common law are to be strictly construed; nor do 1 discuss the clear statement policies used in construing statutes and treaties which define the status of Indian tribes, requiring Congress to speak explicity before it will be deemed to have disestablished an Indian reservation or abrogated Indian treaties (see, e.g., Menominee Tribe of Indians v. United States, 391 U.S. 404, $412-13$ (1968); Mattz v. Arnett, 412 U.S. 481, 504-05 (1973): DeCoteau r. District County Court, 410 U.S. 425. $447(1975)$.

102. "[W]hen choice has to be made between (wo readings of what conduct Congress has made a crime, it is appropriate, before we choose the harsher alternative. o require that Congress should have spoken in language that is clear and definite." United States v. Universal C.1.T. Credit Corp., 344 U.S. 218, $221-22$ (1952). See also United States v. Enmons, 410 U.S. 396 (1973): United States v. Bass, 404 U.S. 336 (1971): Bell v. United States. 349 U.S. 81 (1955); United States v. Wiltberger, 18 U.S. (5 Wheat.) 76 (1820).

103. McBoyle v. United States, 283 U.S. 25,27 (1931).

104. United States v. Bass, 404 U.S. at 348: Huddleston $v$. Uniced States, 415 U.S. 814 (1974).

105. United States v. Bass, 404 U.S. at 348. 
Nor do the courts generally permit the executive to take other steps that curtail liberties in the absence of clear congressional authorization. In some cases the courts invoke the doctrine that statutes will be narrowly construed to avoid constitutional doubts-thereby setting aside the executive action at least until Congress more clearly mandates it and forces resolution of the constitutional question. ${ }^{106}$ In other (and for present purposes more relevant) cases involving individual liberties, constitutional doubts do not necessarily exist; nevertheless, here too, courts forbid the executive action absent clear congressional authorization. In Kent $\%$. Dulles ${ }^{1117}$ for example, the court struck down regulations promulgated by the Secretary of State that would, in effect, have denied passports to communists. The statute relied upon by the Secretary authorized him to "grant and issue passports ... under such rules as the President shall designate and prescribe ...."11"8 The court did not reach, nor explicitly invoke the doctrine to avoid arguments that the Secretary's restrictions on exit were unconstitutional, although it indicated that potential constitutional questions were involved. Rather, the Court struck down the restrictions because Congress had not authorized them in explicit terms: ${ }^{119}$

If that "liberty" is to be regulated, it must be pursuant to the lawmaking functions of the Congress. . . And if that power is delegated, the standards must be adequate to pass scrutiny by the accepted tests. . . Where activities or enjoyment, natural and often necessary to the well-being of an American citizen, such as travel, are involved, we will construe narrowly all delegated powers that curtail or dilute them. . . We hesitate to find in this broad generalized power an authority to trench so heavily on the rights of the citizen.

In numerous other cases, the Supreme Court, without reaching constitutional issues or invoking the doctrine of narrow construction to avoid constitutional doubts, has prohibited sensitive executive action simply because clear and specific legislative authority was essential and none was present. ${ }^{111}$ These

106. Sep note 97 supra. Although these cases often imply that the executive action taken would be held unconstitutional even if Congress were clearly to authorize it, the absence of an unavoidably clear congressional authorization allows the court to construe the statute "narrowly," to void the executives action simply as unauthorized by statute, and to avoid a constitutional decision until Congress itself more clearly reviews and forces the issue.

107. 357 U.S. 116 (1958).

108. Act of July 3, 1926, 22 U.S.C. \$ $211($ a) (1970).

109. Kent v. Dulles, 357 U.S. at 129 (citations omitted).

110. In Duncan v. Kahanamoku, 327 U.S. 304 (1946), the Court held that the statute permitting the President and the Governor of Hawaii to place Hawaii under "martial law" did not permit them to supplant civilian courts by military tribunals. Noting that Congress "did not explicitly declare" that civil courts could be supplanted, Justice Black rejected such authority in light of "principles and practices developed during the birth and growth of our political institutions." The Court did not reach any of the constitutional issues tendered. Id. at 315.319.

In Greene v. McElroy, 360 U.S. 474 (1959), the Court held that the Secretary of Defense did not have the authority to suspend a person's security clearance without certain procedural protections, because such authority had not been delegated to him "explicitly." The Court held that it would not permit "traditional forms of fair procedure" to be "restricted by implication or without 
cases suggest that, whether or not the Constitution requires it, the Court as a matter of statutory construction will not permit the executive to curtail personal liberties without clear authorization.

Finally, there are cases that require clear and express congressional authorization where the policies at stake do not necessarily involve individual liberties at all. These cases are the strongest analogy to the more general clear statement approach that I have proposed. Where an action affects the federal/state balance, for example, the courts will generally require express authorization. As the Supreme Court said in United States v. Bass: ${ }^{111}$

[U]nless Congress conveys its purpose clearly, it will not be deemed to have significantly changed the federal-state balance. . . . In traditionally sensitive areas, such as legislation affecting the federal balance, the requirement of clear statement assures that the legislature has in fact faced, and intended to bring into issue, the critical matters involved in the judicial decision.

the most explicit action by the Nation's lawmakers, even in areas where it is possible that the Constitution presents no imhibition." Id. at 508 (emphasis added). "Without explicit action by lawmakers," the Court noted, "decisions of great constitutional import and effect would be relegated by default to administrators who, under our system of government, are not endowed with authority to decide them." Id. at 507. The Court observed that it was not "clear" that either Congress or the President "specifically has decided that the imposed procedures are necessary and warranted and has authorized their use." Id . at 507.

In NLRB v. Fruit and Vegetable Packers, 377 U.S. 58 (1964), the Court held that the National Labor Relations Act did not forbid "secondary consumer picketing." The Court noted that picketing was generally a "sensitive area" under the First Amendment, which Congress had usually dealt with explicitly, and therefore, the Court said, it would "not [ascribe] to Congress a purpose to outlaw peaceful picketing unless "there is the clearest indication in the legislative history" .. that Congress intended to do so..." $I d$. at 63 .

In Gutknecht v. United States, 396 U.S. 295 (1970), the Court struck down Selective Service regulations that accelerated induction for registrants declared "delinquent." The Court found that the delinquency regulations gave local boards a "broad, roving authority . . not congenial to our lawmaking traditions." $I d$. at 306 . Citing Kent v. Dulles and "constru[ing] narrowly" the Selective Service Act, the Court found that the delinquency regulations were not "specifically atthorized." Id. at 306-07.

See also Schneider v. Smith, 390 U.S. 17 (1968); Cole v. Young, 351 U.S. 356 (1956); United States v. Minker, 350 U.S. 179, 188 (1956). Cf. Watkins v. United States, 354 U.S. 178 (1957); Sweezy v. New Hampshire, 354 U.S. 234, $251-54$ (1957) (plurality opinion); United States v. Rumely, 345 U.S. 41 (1953). There are, of course, cases pointing the other way: e.g., Cafeteria Wrks. Local 473 v. McElroy, 367 U.S. 886 (I96I); Zemel v. Rusk, supra notes 7, 34; Ludecke v. Watkins, supra note 91

111. 404 U.S. at 349. Bass involved federalism values in criminal jurisdiction. See also United States v. Walker, 489 F.2d 1353, 1357 n.16 (7th Cir. 1973) (Stevens, J.), cert. denied, 415 U.S. 982 (1974). ("We have also required that a federal prosecution of an offense historically a matter of State concern be expressly authorized by Congress.") Federalism values have also triggered a clear statement approach in the context of labor antitrust issues, A pex Hosiery Co. v. Leader, 310 U.S. 469, 513 (1940), and environmental regulation, Brown v. Environmental Protection Agency, 521 F.2d 827. 834 (9th Cir. 1975), cert. pending; District of Columbia v. Train, 521 F.2d 971, 984-85 (D.C. Cir. 1975), cert. pending. Cf. Bickel and Wellington, Legislatize Purpose and the Judicial Process: The Lincoln Mills Case, 71 Harv. L. Rev. 1 (1957).

Although Bass noted that a clear statement would be appropriate in "traditionally sensitive areas"- a broad, if vague, formulation-federalism issues directly implicate constitutional policies. Therefore, cases applying a clear statement approach where the federal/state balance is at stake are arguably only a limited analogy to the more general clear statement approach. 
The Court has also said that it would require Congress to "have made its design plain" before interpreting the National Labor Relations Act in a way that would have "far-reaching results" for labor/management relations. ${ }^{12}$ Numerous other judicial opinions have said that a "novel [regulatory] approach,"113 a policy having "profound impacts,"114 a policy marking "a sharp break with our traditions," 115 or simply "a controversial policy choice" 116 could not be implemented unless Congress had indicated clearly that it wanted it.

These cases generally stop the executive or agency from doing something, but that is not really the point. The courts in all of them are really concerned with an institutional question: Who, in our system, should be making this decision? In Alexander Bickel's phrase, the courts are "recall[ing] the legislature to its own policy-making function." 117 The judgment that rests behind each case is that the policy decision involved is "too important to be made by anyone but the legislature." 118 Moreover, it is too important to permit legislative authorization to be inferred. In many of these cases, there had been legislative involvement of sorts-a generally phrased statute that arguably authorized the action, ${ }^{119}$ or a subsequent congressional appropriation that might have been viewed as implicit approval of the administrative choice. ${ }^{12 "}$ But where the action involved is of large importance, implied authorization is insufficient. Explicit and clear action by the legislature is required. ${ }^{121}$

When is a clear statement approach properly used to "recall the legislature to its own policy-making function?" 122 If, as the clear statement cases indicate, policy questions affecting individual liberties are too important to be left to

112. NLRB v. Bell Aerospace Co., 416 U.S. 267, 289 n. 18 (1974).

113. District of Columbia v. Train, supra note 111, 521 F.2d at 984. See also Turner v. F.C.C., 514 F.2d 1354 (D.C. Cir. 1975); Accuracy in Media, Inc. v. F.C.C., supra note 92.

114. National Woodwork Mfrs.. Assin, 386 U.S. 612, 648-50 (1967) (Memorandum of Harlan, J.): see also Packard Motor Car Co. v. NLRB, 330 U.S. 485. 493-501 (1947) (Douglas, J., dissenting).

115. National Cable Television Ass'n, Inc. v. United States, 415 U.S. at 341; see also Girouard v. United States, 328 U.S. 61, 64 (1946).

116. FPC v. New England Power Co. 415 U.S. 345. 357 (concurring and dissenting opinion).

117. A. Bickel, supra note 7 at 161 .

118. Id. at 181 .

119. E.g. Kent v. Dulles, supra note 109.

120. E.g. Greene v. McElrov, supra note 110,360 U.S. at 506-08.

121. Implicit congressional ratification through appropriations or acquiescence is often found, e.g. Brooks v. Dewar. 313 U.S. 354, 361 (1941): United States v. Midwest Oil, 236 L.S. 459 (1915); but the courts have made clear that in areas of special importance and sensitivity. congressional approval of executive action cannot be assumed by "acquiescence or implied ratification." Greene v. McElroy, supra note 110, 360 U.S. at 506; see also Zuber v. Allen, 396 U.S. 168 (1969); Kent v. Dulles, supra note 107; Ex parte Endo, 323 U.S. 283, 303 n. 24 (1944).

122. A. Bickel, supra note 7 at 161. Although Professor Bickel's discussion of narrow construction of statutes mainly concerns areas of constitutional sensitivity, he appears to agree that narrow construction may serve useful purposes "not only when constitutional issues would otherwise have to be adjudicated." He notes that "[s]uch was the method by which the Sherman Antitrust Act was at last held not applicable to union activities aimed at exerting labor's economic bargaining power." Id. at 181 . 
anyone but the legislature, is this not true of major questions of social and economic policy as well? And therefore should not the clear statement approach have a place in both situations? Congress' article 1 powers, after all, cover both, and clear legislative authorization for major social and economic policies may be as important as legislative authorization for sensitive actions involving individual liberties. Indeed, these social and economic policies may by their nature be even more suited to majoritarian legislative resolution than issues affecting personal liberties, since these liberties often involve interests against the majority and therefore restrictions on such liberties can generally not be legitimated by majoritarian authorization.

There are, admittedly, special problems if the clear statement doctrine is applied, as 1 suggest, in connection with decisions not related to constitutional policies. How are courts to determine whether a particular policy decision is of the sort that should trigger a clear statement approach? All clear statement doctrines have this problem to some extent, along with the intertwined problem of how clear the congressional authorization must be. ${ }^{123}$ But where a decision affects interests within the vicinity of protected constitutional rights, as in Kent $\%$. Dulles, the judicial judgment to require clear congressional authorization may at least be justified by reference to well established values. By what manageable criteria, however, is a large oil tariff deemed important enough to require clear legislative authorization, but not some other governmental action? There is, to be sure, an element of subjectivity in this judgment (like that already discussed in connection with the delegation doctrine). ${ }^{2+}$ But the judgment rests upon factors that, as we have seen, the courts appear prepared to assess in other clear statement cases: how "farreaching" a policy is, how "controversial," how "novel" in light of past policy and principle, how much "impact" a policy will have and on how many people. ${ }^{125}$ Similar factors are assessed by courts in other situations. ${ }^{126}$ They

123. See Stewart, supra note 7 at 1681 n. 54,1788 .

124. See notes 63-66 supra and accompanying text.

125. See notes 110-115 supra and accompanying text.

126. The courts assess the importance of policies in deciding whether to grant equitable relief. See. e.g., Boys Markets, Inc. v. Retail Clerks, Local 770, 398 U.S. 235, 252 (1970), discussing Brotherhood of R.R. Trainmen v. Chicago River \& Ind. R.R., 353 U.S. 30 (1957) (equitable relief available because "an important federal policy was involved in the peaceful settlement of disputes through the statutorily mandated arbitration procedure . . . .); Gateway Coal Co. v. United Mine Workers, 414 U.S. 368, 382 (1974) (equitable relief available because of "strong federal policy favoring arbitration of labor disputes"): Bradley v. Richmond School Bd., 416 U.S. 696, 717 (1974) (application of existing law depends on nature of the parties and nature of the right), following United States v. Schooner Peggy, 5 U.S. (1 Cranch) 103, 110 (1801) ("in great national concerns ... the court must decide according to existing laws"). The courts also assess the importance of interests at stake in evaluating the scope of application of the due process clause, e.g., Goss v. Lopez, 419 U.S. 565 (1975); Goldberg v. Kelly, 397 U.S. 254 (1970); the right to travel, e.g., Memorial Hospital v. Maricopa County, 415 U.S. 250 (1974); but of. Sosna v. Iowa, 419 U.S. 393 (1975); and the equal protection clause, e.g., Dunn v. Blumstein, 405 U.S. 330 (1972); Douglas v. California, 372 U.S. 353 (1963); but cf. San Antonio Independent School District v. Rodri- 
can probably be managed here as well-particularly if the doctrine is confined to relatively extreme cases.

The legitimacy of the clear statement approach, in the end, rests upon its modesty in the service of fundamental constitutional principle. To the extent that it is judicial activism, its goal is primarily to assure more representative and accountable decision making. It opposes executive power in some circumstances, but not when that power is clearly and explicitly authorized. It encourages and invites Congress to make policy choices, but, if Congress really prefers not to, Congress has its way. It interprets statutes in light of a constitutional policy, but does not impose a constitutional requirement. The court resists a departure from article I principles, but the court does not preclude anything permanently.

To be sure, judicial intervention is not the only recourse available to restrain the executive. Just as Congress, without judicial intervention, is able to try to overrule the executive when it violates a clear statutory command, a dissatisfied Congress is free to try to overrule the executive when it expansively interprets ambiguous or generally phrased statutes in a way that Congress opposes. The possibility that Congress might act without any judicial assistance certainly does not preclude a judicial role in the former situation (where congressional action is most likely because the executive affront is most blatant), nor should it in the latter. At the risk of some repetition, it is worth underscoring some of the structural reasons ${ }^{127}$ why judicial intervention is appropriate here.

First, Congress cannot simply "overrule the executive" when it objects to the executive's interpretation of a statute. Overrule can generally be accomplished only by means of repeal or amendment of the statute in question, ${ }^{128}$ and this is subject to a (likely) presidential veto; thus a super-majority of twothirds of each house would be needed to rein in expansive executive policymaking. ${ }^{129}$ In fact, shortly after President Ford imposed the oil import fees,

guez, 411 U.S. 1 (1973). But of. Alyeska Pipeline Service Co. v. Wilderness Society, 421 U.S. 240, 263-64 (1975) (courts will not use inherent equitable powers in order to award attorneys fees to "private attorneys general" who enforce federal law, because, inter alia, such an approach would require courts to determine which statutes were important enough to warrant this incentive to their enforcement).

127. Interwined, of course, are the material interests of the private parties who are affected by the executive action (e.g., potential recipients of impounded funds) and who are seeking a judicial determination of their claims.

128. This simplifies things, of course. For example, the appropriations process gives Congress great leverage over spending programs, and Congress can, if it has the will, use leverage over pending legislation and appropriations to secure leverage over the implementation of programs already operating. Congresspersons can also mobilize public pressure against the President.

129. Congress might, of course, pass statutes which require the executive or agencies to lay before Congress major and minor actions which implement the statute and permit Congress, one House, or a Committee to set aside such actions by affirmative resolution or even by simply failing to approve them within a fixed time, neither step subject to presidential veto. There has, 
Congress did pass a bill suspending the fees, but the President vetoed it. ${ }^{130}$

Second, when Congress is faced with an executive policy that is in place and functioning, Congress often acquiesces in the executive's action for reasons which have nothing to do with the majority's preferences on the policy issues involved. ${ }^{131}$ In such a situation, Congress may not want to be viewed as disruptive; or Congresspersons may not want to embarrass the President; or Congress may want to score political points by attacking the executive's action rather than accepting political responsibility for some action itself; or Congresspersons may be busy running for reelection or tending to constituents' individual problems; or Congress may be lazy and prefer another recess; or there may just be inertia because some policy is functioning. For these reasons and others. congressional review of executive policy-making is sporadic, and the executive frequently makes policy without Congress' either taking responsibility for it or repudiating it. The result is a system sharply skewed towards executive policy-making. But Congress' sense of responsibility might well be different if the court had wiped the slate relatively clean and Congress were faced with a national problem that would not be addressed until Congress took affirmative action. To be sure, Congress could still decide to pass the buck to the executive or take a holiday, but Congress' will to

in fact, been legislation along these lines in the past, and there appears to be a growing movement in this direction. Washington Post. Dec. 27, 1975. at 2 col. I. See generally, E. Corwin, The President: Office and Powers 129-30 (1957): W. Gellinorn and C. Byse, Administrative Law: Cases and Comments 122-27 (6th ed. 1974); B. SChwartz, A Commentary on the Constitution of the United States: The Powers of Government 33-35 (1963); Ginnane, The Control of Federal Administration by Congressional Resolutions and Committees, 66 HARv. L. Rev. 569 (1953); Watson, Congress Steps Out: A Look at Congressional Control of the Executive, 63 CaLif. L. Rev. $983(1975) ; c f$. Cutler and Johnson, supra note 21.

For me. such legislation poses difficult questions of policy and constitutionality. even though I clearly approve of its goal (to strengthen Congress' role in checking the executive) and its attempt to achieve that goal within the political process itself without use of the courts. It would require much time and space to discuss the issues, but I briefly comment on the constitutional questions. Leaving aside the potential constitutional problem of lawmaking by one House or a Committee, the proposals all raise constitutional questions because they permit Congress, in effect. to repeal (and effectively amend) the clearest of statutes without permitting the President to veto. It is not, I believe, an altogether satisfactory answer to this argument to say that the interests of the Presidency are adequately protected by the option, always available to the President, of vetoing the initial legislation which dilutes the President's veto power. A President who signs the bill might effectively waive his own personal veto prerogatives, but could he waive his successor's veto prerogatives? And if a statute dilutes the Presidents veto power has not something gone awry in the constitutional system which no concurrence among the occupants of two political branches should be able to insulate from challenge? See also note $4 \mathbf{1}$ supra.

130. See Algonquin SNG, supra note 80,518 F.2d at 1054 n. 6. On vetoing the bill, the President did briefly suspend the imposition of the fees announced in his proclamation, although he eventually phased in most of the anticipated fees. The recently passed Energy Conservation and Policy Act, Pub. L. No. 94-163, which President Ford signed, requires the President to develop within 180 days energy conservation contingency plans which may not provide for any "tax" or "tariff." $\$ 202(\mathrm{a})(2)(\mathrm{A})$. Upon signing the bill the President announced that he would remove most of the import fees that he had previously imposed.

131. Cf. note 41, supra; Jaffe, supra note 7 , at 359, 369-70. 
accept responsibility for policies would probably be strengthened if an executive policy were not in place. In short, some external push from the judiciary may be useful in stimulating Congress to express its policy preferences.

Finally, to the extent that the courts' narrow reading of the statute in effect requires Congress to reconsider what it thought it had already authorized (albeit in an ambiguous or general way), the burden placed upon Congress to take clearer responsibility for major policies furthers constitutional values. Major executive policy-making represents a fundamental shift in our constitutional system-whether or not Congress agrees to it. A significant constitutional principle is at stake, and in using the clear statement doctrine the courts play the important function of placing that principle before the political branches-reminding them of it and, in effect, requiring them to consider it before they act. The courts play a unique role in our system in articulating principles, and the particular principle involved here-the proper boundaries of each branch-is one legitimately protected by the judiciary in our system. ${ }^{132}$ If Congress should decide in the end that it wishes to defer to the executive, it will at least do so fully aware of the principle at stake.

\section{B. Statutory Construction as a Control on the President's Inherent Powers}

The scope of the President's powers to make policy absent statutory authorization is a subject that both the courts and I leave mostly to others. However, one judicial doctrine concerning these powers is so clearly related to the previous discussion that I mention it briefly. This doctrine comes into play when the President asserts inherent powers in an area also within Congress' article I powers.

For such a situation, the law appears to be the following: If Congress has already acted to "preempt the field" or "cover the situation,"133 the President may not take any action inconsistent with Congress' action. This is potentially a major doctrine for limiting presidential power.

An early illustration of this approach is the extraordinary case of Little $\%$. Barreme, decided in 1804. ${ }^{134}$ The Supreme Court upheld an award of damages against a ship captain who, on specific order of the President, seized a ship coming from France. As Commander in Chief or pursuant to the "take care" clause of article II, the President might well have had article II authority to order the seizure of ships bound both to and from France, the Court said. But since Congress had passed a nonintercourse act which simply authorized seizures of ships going to France, the legislation had "prescribed . . . the manner" in which the law "shall be carried into execution." Thus the

132. See notes 62 and 71 supra and accompanying text.

133. The phrases are from A. Schlesinger, supra note 6, p. 148.

134. 6 U.S. (2 Cranch) 170 (1804). 
President's order was unlawful, and the captain who made the unlawful seizure was found liable for damages.

A more famous example is Youngstown Sheet $\xi^{2}$ Tube Co. v. Sawyer, ${ }^{135}$ where the Court enjoined President Truman's seizure of the country's steel mills to end a labor-management dispute during the Korean War. Since there was no statutory authorization for the seizure, the main issue was whether the President had inherent constitutional power to act. Justice Black's opinion of the Court held that the seizure order was "law-making" which was for Congress, not the President, in our constitutional framework. But in light of various opinions of the concurring justices necessary for the majority, the case now is often thought to stand for a narrower proposition, ${ }^{136}$ articulated most vividly in Justice Jackson's theory of the twilight zone. In the twilight zone the President and Congress may both have the power to act, but if Congress acts the President's power is "at its lowest ebb." Thus, in evaluating the President's action, it was of critical significance that Congress had provided for seizure and other emergency actions in certain situations (none of which were invoked by the President). Congress had thereby covered the field with statutory policies inconsistent with the steel seizure, and the President could not act.

Why, if concurrent authority exists, should Congress and not the President be able to preempt the field? The explanation, presumably, is that Congress is thought to be the preferred policy-maker in our system. The preemption doctrine strengthens Congress' policy-making role; preemption not only assures that Congress' prior policy decisions are protected, but also leaves the field open to Congress for further action.

For those concerned about the President's assertion of broad inherent powers, it may often be more profitable to argue that Congress has preempted the field than that the President has no inherent authority to act. The critical question then becomes: When is Congress deemed to have preempted the field? This is essentially a question of statutory interpretation. In neither Little \%. Barreme nor Youngstozun had Congress explicitly precluded the action that the President wanted to take. The statutory interpretation question essentially turned on the significance of silence.

The answer to such a question largely depends upon a careful analysis of the specific legislative materials involved in each case. But external principles usually play a role in the interpretive effort. Since the preemption doctrine reflects a clear preference for congressional policy-making, that preference should probably also guide determination of whether congressional preemption has occurred in a particular case. The basic principle is the same as the one discussed in the previous section: Where an important policy decision is

135. 343 U.S. 579 (1952)

136. E.g., Corwin, The Steel Seizure Case: A Judicial Brick Without Straw, in Essays IN Constitutional. Law 257 (R. McCloskey ed. 1957). 
within Congress' article I power to make, it will not be lightly assumed that the executive is permitted to make the decision. But since the President's own constitutional powers may be at stake, the principle should be applied here only in close cases. Under such an approach, the courts would resolve doubtful questions by finding congressional preemption and presidential inconsistency, thereby preserving the congressional policy-making role, at least where the presidential action is of large significance.

The importance of this approach to determining whether the President has been preempted is suggested by the recent case of Consumers Union $v$. Kissinger, decided by the U.S. Court of Appeals for the District of Columbia. ${ }^{137}$ The President had entered into agreements with foreign steel producers to limit their steel shipments to the United States. The questions were whether he had the authority to do so at all and whether he was required to follow congressionally mandated procedures designed to assure public airing of trade issues. The majority held that the President had inherent authority to regulate foreign commerce by entering into the import restraints in question, and that Congress had most likely preempted the field of "enforceable" import restraints by prescribing substantive and procedural requirements. But the majority found that no conflict existed between the President's steel quota agreement and congressional legislation in the trade area since the steel quotas involved "voluntary" and non-"enforceable" restraint by the foreign producers; therefore, the President need not follow the congressionally mandated requirements and procedures.

Judge Leventhal dissented. While the President might well have inherent powers concerning foreign commerce, Judge Leventhal said, the President could not "manage foreign commerce in a manner lying outside a comprehensive, regulatory scheme Congress has enacted pursuant to its article I, $\S 8$ power." 138 The President's action in this case was inconsistent with such a scheme "occupying the field of import restraints" and requiring a prescribed "procedure with safeguards and right of comment by affected interests." Whether or not the steel agreements were enforceable (and Judge Leventhal suggested that they were), the nature and effect of the restraint agreements made them subject to the procedural and substantive restrictions of the legislation. The restraints admittedly failed to meet these requirements and therefore the President's independent action was unlawful.

The question, therefore, turned on whether Congress had preempted the field. The divergence between majority and dissent on this question depended to some extent on different views concerning the nature of the particular restraint and the legislative scheme. The divergence also rested in part upon a

137. 506 F.2d 136 (1974). cert. denied, 42I U.S. 1004 (1975).

138. 506 F.2d at 149 . 
different conception of how significant it was that the President had failed to use the required procedures. ${ }^{139}$ For Judge Leventhal, not surprisingly, the procedures were "no mere technicalities," but were critical to prevent abuses and encourage better policy in an area where the President otherwise may have had broad discretion. ${ }^{140}$

But the most significant factor in Judge Leventhal's conclusion that the President had been preempted may have been the importance that he attached to protecting Congress' role in the policy-making process. At the end of his opinion, he gives expression to a basic principle: "Where, as here, the power of Congress to regulate a matter committed expressly to it by the Constitution is at stake, a close case should be decided so as to protect Congressional power." 141

\section{Conclusion}

I have suggested several ways in which the courts can try to stem the flow of article $I$ power from Congress to the executive and return policy-making decisions to Congress. But if the flow is to stop, the decisive effort, in the end, must be made by Congress. Justice Jackson was right to vote as he did in the Youngstown case, but he was also right to add: ${ }^{142}$

I have no illusion that any decision by this Court can keep power in the hands of Congress if it is not wise and timely in meeting its problems. . . We may say that power to legislate for emergencies belongs in the hands of Congress, but only Congress itself can prevent power from slipping through its fingers.

The courts can try to lead and encourage, but in large things their achievements depend upon their ability to inspire consent and will in others. John Stuart Mill once wrote that "[a] government must be composed out of elements already existing in society, and the distribution of power in a constitution cannot vary much or long from the distribution of it in society itself." 143 The courts cannot imagine an allocation of power between the branches that is unrealistic, and expect to impose it. Congress' policy-making role will not be strengthened or protected from executive encroachment simply because the courts recite constitutional principles and pass a number of policy issues back to Congress.

139. Judge Leventhal thought it "likely" that the President would have substantive statutory authority for the agreements if he claimed it.

140. Id. at 156, citing, inter alia, Kenneth Davis and the Amalgamated Meat Cutters opinion.

141. Id. at 158. "[S]ensitive to the delicacy of the issue of preemption," and "in deference to possible clarification or correction by the President and Congress together," Judge Leventhal would have withheld the court's mandate for 90 days.

142. 343 U.S. 579, 654 (1952).

143. J, Mill, On Bentham and Coleridge 154 (1962). 
What the courts can do most easily is to put reason and principle and a little power behind a congressional will which already exists, or is very close to the surface; in the impoundment area, for example, the courts legitimated the congressional perspective, and probably made it easier for the Congressional Budget and Impoundment Control Act of 1974 to win acceptance and passage. Where the congressional will is not so near at hand, the courts can try to inspire it, or try to create an incentive for its expression by resisting congressional abdication and refusing to permit the executive to make broad policy without going to Congress. But if Congress is not receptive, the courts in the end will probably have to back off.

Moreover, congressional reform is probably a predicate for any greatly strengthened policy-making role. Better staff, better information sources, better internal organization and coordination are all essential. Since a disorganized Congress cannot be called unlawful-even absent clear authorization-congressional reform is beyond the courts' ability to control directly. It is arguable, however, that Congress has been weakened internally by court decisions that continue to uphold and embellish loosely drafted statutes which broadly delegate power; and so it is possible that congressional reform efforts can be strengthened indirectly by judicial actions which encourage more congressional policy-making responsibility. Even so, it may be that none of the conventionally touted reforms would make enough of a difference. It may be that Congress, because of its size, composition, and its reelection fixation, cannot change enough to play its preferred role.

Nor is it clear that the people want it to change. The emotion of a populace faced by an endlessly confusing world is probably to want decisive, visible, and perhaps authoritarian leadership. ${ }^{144}$ Congress can never really provide this in the way the President can. Nor can it provide the ordinary citizen the opportunities of a more personalized participation that may be found in local communities. Alongside those who want stronger leadership, there are those who want less federal government of all kinds (they may even be the same persons). Of those who are left, how many people care which branch of the national government exercises power? In short, in the slow struggle to regain power against the executive, Congress' popular support may not be strong.

I do not mean to depart from what I have said earlier about the appropriateness of Congress' playing a more decisive policy-making role. These closing observations simply note an additional perspective of limitation from which I think about the other issues. My point, in the end, must be a modest one. The power of the executive branch and the agencies today rests in sig-

144. Cf. Heilbroner, What Is the Human Prospect? XX The New York Review, Jan. 24, 1974, at 21 . 
nificant part upon their broad policy-making power, largely claimed pursuant to congressional statutes. It is often suggested that Congress needs to be strengthened in our system by recovering much of this policy-making power. The judicial doctrines that I have discussed all address that objective. Most of the arguments against these various judicial doctrines rest upon the belief that congressional performance in making policy cannot be substantially improved. And if that is the case, we must wonder whether executive power can be significantly controlled. 